\title{
A green garlic (Allium sativum L.)-based intercropping system reduces the strain of continuous monocropping in cucumber (Cucumis sativus L.) by adjusting the micro-ecological environment of soil
}

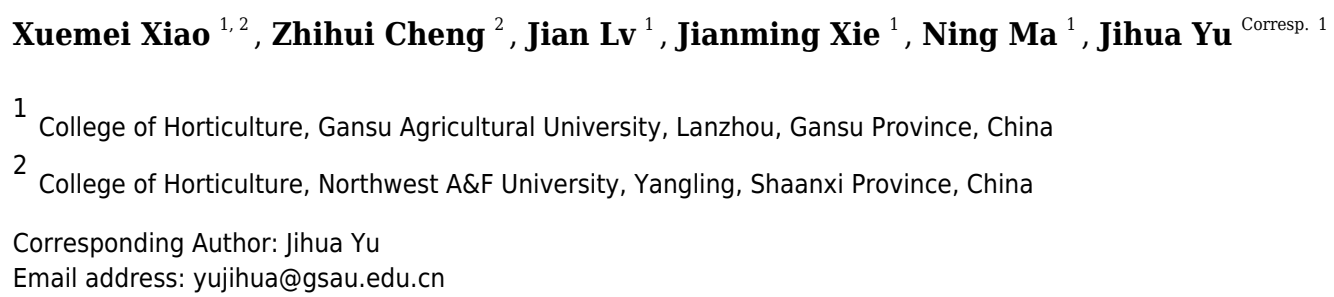

Continuous cropping obstacle of cucumber (Cucumis sativus L.) under facility cultivation is more prevalent in China. This is associated with imbalance in soil microbial and ecological environment in long-term monocultures. It was postulated that intercropping with green garlic would relieve the continuous cropping obstacle of cucumber by altering the soil micro-ecology status. A pot-based experiment was conducted to investigate the green garlic-cucumber intercropping and cucumber monocropping systems. The results showed that the cucumber shoot biomass was improved by intercropping with green garlic. However, the population of soil bacteria and actinomycetes increased, while the fungal population decreased. The fatty acid methyl ester (FAME) profiles indicated that soil

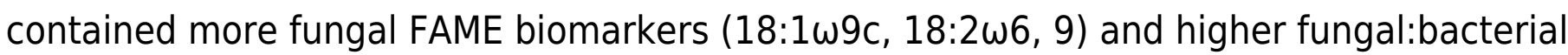
ratio in the monoculture system, whereas clustering of more bacterial FAME biomarkers (cy17:0, cy19:0, 16:1w7c10, Me16:0, 10Me17:0, 10Me18:0) was observed under intercropping conditions. Moreover, significantly $(P<0.05)$ higher soil invertase and alkaline phosphatase activities, organic matter, and available $\mathrm{N}, \mathrm{P}$ and $\mathrm{K}$ contents were observed under intercropping systems. These were high in both bulk and rhizosphere soils in the intercropping system when compared to monocropping system. These findings suggest that intercropping with green garlic can alleviate continuous cropping obstacle of cucumber by improving the diverse composition of soil microbial community, enzyme activities, and nutrient availability. 
1 A green garlic (Allium sativum L.)-based intercropping

2 system reduces the strain of continuous

3 monocropping in cucumber (Cucumis sativus L.) by

4 adjusting the micro-ecological environment of soil

5

Xuemei Xiao ${ }^{1,2}$, Zhihui Cheng ${ }^{2}$, Jian $\mathrm{Lv}^{1}$, Jianming Xie ${ }^{1}$, Ning Ma ${ }^{1}$, JihuaYu ${ }^{1 *}$

${ }^{1}$ College of Horticulture, Gansu Agricultural University, Lanzhou, Gansu Province, China

${ }^{2}$ College of Horticulture, Northwest A\&F University, Yangling, Shaanxi Province, China

Corresponding Author:

$\mathrm{JihuaYu}^{1 *}$

No. 1 Yingmen Village, Lanzhou, Gansu Province, 730070, China

Email address: yujihuagg@163.com; yujihua@gsau.edu.cn

\section{Abstract}

Continuous cropping obstacle of cucumber (Cucumis sativus L.) under facility cultivation is more prevalent in China. This is associated with imbalance in soil microbial and ecological environment in long-term monocultures. It was postulated that intercropping with green garlic would relieve the continuous cropping obstacle of cucumber by altering the soil micro-ecology status. A pot-based experiment was conducted to investigate the green garlic-cucumber intercropping and cucumber monocropping systems. The results showed that the cucumber shoot biomass was improved by intercropping with green garlic. However, the population of soil bacteria and actinomycetes increased, while the fungal population decreased. The fatty acid methyl ester (FAME) profiles indicated that soil contained more fungal FAME biomarkers $(18: 1 \omega 9 \mathrm{c}, 18: 2 \omega 6,9)$ and higher fungal:bacterial ratio in the monoculture system, whereas clustering of more bacterial FAME biomarkers (cy17:0, cy19:0, 16:1ఱ7c10, Me16:0, 10Me17:0, 10Me18:0) was observed under intercropping conditions. Moreover, significantly $(P<0.05)$ higher soil invertase and alkaline phosphatase activities, organic matter, and available N, P and $\mathrm{K}$ contents were observed under intercropping systems. These were high in both bulk and rhizosphere soils in the intercropping system when compared to monocropping system. These 
32 findings suggest that intercropping with green garlic can alleviate continuous cropping obstacle 33 of cucumber by improving the diverse composition of soil microbial community, enzyme activities, and nutrient availability.

\section{Introduction}

The successive plantation of the same crop on the same land results in the reduction of crop yield and quality under normal cultivation management, and this is known as the 'continuous cropping obstacle'. Several lines of evidence suggest that increased soil-borne diseases, soil acidification, secondary salinization, and soil microbial ecology imbalance are the reasons for this phenomenon (Yao et al. 2006; Zhou et al. 2012, 2014). The problem is becoming increasingly severe in agricultural production, especially in facility cultivation, which certainly remains to be a crucial challenge for sustaining agriculture. Therefore, it is necessary to seek an effective alternative method to overcome this shortfall.

An intercropping system is where two or more crops are grown together in the same period and in the same field. This system not only enhances resource utilization (Hamzei and Seyyedi, 2016) but also improves the soil's physical quality (Latif et al. 1992), eventually increasing the productivity of the crop (Wu et al. 2016). Studies have shown that the soil nutrient availability, soil enzyme activities, and microbial diversity were comparatively higher under intercropping conditions than in the monocropping system (Tian et al, 2018; Li et al. 2013; Li et al. 2016; Wahbi et al. 2016). Based on the benefits of intercropping system in agriculture, more and more scientists have focused on its application to relieve successive cropping obstacles. Many studies have demonstrated that the intercropping system of suitable species could alleviate the continuous cropping obstacle of the target crop, such as onion-cucumber (Zhou et al. 2011), cumin, anise, onion, garlic-lentil (Abdel-Monaim and Abo-Elyousr 2012) and wheat-watermelon (Xu et al. 2015). Additionally, intercropping could reduce soil-borne diseases (Xu et al. 2015) and cause changes in soil enzyme activities as well as microbial communities (Acosta-Martínez and Cotton 2017; Li and Wu 2018; Dai et al. 2013).

Soil enzymes act as sensitive indicators of soil quality and play a key role in organic matter decomposition and nutrient transformation (Bowles et al. 2014). According to the previous studies, crop rotation has improved the activities of amylase, cellulase, arylsulfatase and phosphatase. Soil enzyme activities have also shown significant correlations with total organic carbon, and carbon and nitrogen microbial biomass (Balota et al. 2004). Soil microbial communities share a role in many ecological processes, such as nutrient cycling, organic matter decomposition and soil structure formation (Cotton et al. 2013). It has been observed that intercropping systems significantly reduce the fungal to bacterial ratios (F: B) and fungal biomass while increasing the soil enzyme activities (Acosta-Martínez and Cotton 2017). A 
67 profiling study of microbial phospholipid fatty acids (PLFAs) indicated that maize-based 68 intercropping system improved phosphate uptake by modifying the microbial communities including the dominant microbial species (He et al. 2013). Previous studies paid more attention to crop-crop and crop-vegetable intercropping systems, but till date, very few studies have been performed for the vegetable-vegetable intercropping system. Cucumber (Cucumis sativus L.) is a popular greenhouse vegetable in China, but its continuous monoculture has induced cropping obstacles. In recent years, we have tried to develop an effective method to relieve the cropping problems of cucumber. Garlic (Allium sativum L.) is effectively used in the intercropping system due to its allelopathic and antimicrobial characteristics (Khan et al. 2011; Tian et al. 2018). It has been used in several vegetable facilities to relieve the continuous cropping obstacles, such as the garlic-pepper (Khan et al. 2015), garlic-eggplant (Wang et al. 2014, 2015), garlic-tomato (Liu et al. 2014) and garlic-cucumber intercropping systems (Xiao et al. 2012, 2013). Green garlic, similar to the Chinese chive, releases more root exudates by seeding whole garlic bulbs when compared to garlic. So, it is important to understand how and why the intercropping of green garlic influence the continuous cropping of cucumber. This study was designed to investigate the differences between green garlic-cucumber intercropping and cucumber monocropping systems.

\section{Materials \&Methods}

\section{Soil Source and Cultivation}

The test soil used in this study is the dark loessial soil. The $0-30 \mathrm{~cm}$ layer of the soil was collected by hoe and shovel from a plastic tunnel, which had been previously planted with cucumber for five years in Lanzhou, Gansu Province, China. The chemical characteristics of the soil were as follows: electrolytic conductivity ( (soil/water ratio of $1: 1)=7.59$; organic carbon $=14.98 \mathrm{~g} \cdot \mathrm{kg}^{-1}$; total $\mathrm{N}=2.15 \mathrm{~g} \cdot \mathrm{kg}^{-1}$; available $\mathrm{N}$ $=110.13 \mathrm{mg} \cdot \mathrm{kg}^{-1}$; total $\mathrm{P}=1.34 \mathrm{~g} \cdot \mathrm{kg}^{-1}$; available $\mathrm{P}=191.61 \mathrm{mg} \cdot \mathrm{kg}^{-1}$ and available $\mathrm{K}=216.32$ $\mathrm{mg} \cdot \mathrm{kg}^{-1}$. The soil $(17 \mathrm{~kg})$ in each plastic pot $(46 \mathrm{~cm} \times 40 \mathrm{~cm}$ in diameter and height $)$ was mixed with $100 \mathrm{~g}$ of 'GOLD FUFENG' organic fertilizer produced by the Inner Mongolia WOFENG

AGRICULTURE development co. LTD (organic matter $\geqslant 45 \%, \mathrm{~N}+\mathrm{P}_{2} \mathrm{O}_{5}+\mathrm{K}_{2} \mathrm{O} \geqslant 10 \%$ and water content $\leqslant 3 \%), 10 \mathrm{~g}$ of calcium superphosphate $\left(\mathrm{P}_{2} \mathrm{O}_{5} \geqslant 16.0 \%\right)$ and $10 \mathrm{~g}$ of compound fertilizer $\left(\mathrm{N}-\mathrm{P}_{2} \mathrm{O}_{5}-\mathrm{K}_{2} \mathrm{O}: 18-18-18\right)$.

The pot-based experiment included a completely randomized block design with three replicates for each of the following treatments: (1) cucumber (Cucumis sativus L. cv. Xintiandi No. 1) monocropping and (2) cucumber intercropping with green garlic (Allium sativum L. cv. G064). Ten pots were used for each treatment in one replication. 
One cucumber seedling was transplanted at the centre of each pot on August 13. Twenty days later, $450 \mathrm{~g}$ garlic bulbs were uniformly planted around the cucumber plants at a distance of 10-12 cm from the plants. No garlic bulbs were planted for cucumber monocropping. During the experiment, the soil moisture was maintained at approximately $70 \%$ of the field's water-holding capacity. All pots were manually irrigated and hand-weeded during crop growth.

\section{Growth and Photosynthetic Pigment Analyses}

After an interval of 15 days, 30 days and 45 days of intercropping with green garlic, the cucumber plants were uprooted and divided into roots and shoots and were then freshly weighed (g). The dry weights were measured after drying at $75^{\circ} \mathrm{C}$ for $72 \mathrm{~h}$ to a constant weight and after killing the enzymatic activities at $105^{\circ} \mathrm{C}$ for $15 \mathrm{~min}$. The fresh, fully matured young leaves (the fifth leaf below the growing point) were sampled and homogenized in $80 \%$ acetone. The absorbance of the supernatant was read at 470, 649 and $665 \mathrm{~nm}$ by using a spectrophotometer (UV-1800, Shimadzu, Japan). Then the chlorophyll (Chl a, b) and carotenoid contents were determined as described by Arnon (1949).

\section{Soil Sample Collection}

Soil samples were collected three times with 15 days interval after the green garlic was intercropped. Every time when the cucumber plants were dug out, the rhizosphere soil from the cucumber roots was obtained for sampling according to the method described by Zhao et al. (2016). The 0-20 cm layer of bulk soil was sampled by hand from a distance of $3-5 \mathrm{~cm}$ from the cucumber main root in the pot. The collected soil samples were divided into three sections. One portion of the sample was maintained at $4{ }^{\circ} \mathrm{C}$ to analyze the microbial densities, including the bacteria, actinomycetes and fungi. Another portion of the sample was stored at $-70{ }^{\circ} \mathrm{C}$ for analyzing the microbial community diversity and composition. The third portion of the sample was air-dried, pulverized and passed through a $1 \mathrm{~mm}$ sieve for analyzing the enzyme activities, available nutrients, and $\mathrm{pH}$ values; or through $0.149 \mathrm{~mm}$ sieves for analyzing the soil organic $\mathrm{C}$ content.

\section{Soil chemical properties analyses}

The soil organic matter content was determined using the dilution heat $\mathrm{K}_{2} \mathrm{Cr}_{2} \mathrm{O}_{7}$ oxidation volumetric method. The $\mathrm{pH}$ was measured in a 1:1 soil/water suspension. The available $\mathrm{N}$ content was analyzed using the alkali-hydrolytic diffusion method. The available P content was extracted using $1 \mathrm{M}$ sodium bicarbonate $\left(\mathrm{NaHCO}_{3}\right)$ and determined by spectrophotometry. The available $\mathrm{K}$ content was extracted with $1 \mathrm{M}$ ammonium acetate $\left(\mathrm{NH}_{4} \mathrm{Ac}\right)$ and analyzed using an atomic absorption spectrophotometer (Hitachi Z-2000, Tokyo).

\section{Soil enzymes analyses}

The activities of invertase (EC 3.2.1.26), urease (EC 3.5.1.5) and alkaline phosphatase (EC 3.1.3.1) were detected with appropriate substrates and conditions ( $24 \mathrm{~h}$ incubation at $\left.37^{\circ} \mathrm{C}\right)$ 
137

138

139

140

141

142

143

144

145

146

147

148

149

150

151

152

153

154

155

156

157

158

159

160

161

162

163

164

165

166

167

168

169

170

171

172

according to Tabatabai (1994). The activity of catalase (EC 1.11.1.6) was assayed by using the $\mathrm{KMnO}_{4}$ titration method (Johnson and Temple 1964).

\section{Microbial community analyses}

The soil microbial densities were analyzed by using the plate dilution method according to El-Tarabily et al. (1996). The beef broth peptone medium, Gause No. 1 medium, and Martin medium were used to grow bacteria, actinomycetes and fungi, respectively. The numbers of colonies were counted, and the population per gram was calculated based on the oven-dried (105 $\left.{ }^{\circ} \mathrm{C}\right)$ soil weight.

The structural diversity and composition of soil microbial communities were analyzed by the PLFA method. The PLFA extraction and purification procedures were performed according to the methods described by Mbuthia et al. (2015). Briefly, $6 \mathrm{~g}$ (freeze-dried weight) of soil was extracted using a mixture of chloroform, methanol and citrate buffer (1:2:0.8). The chloroform layer was collected and then dried under nitrogen gas at $37^{\circ} \mathrm{C}$. The neutral lipids, glycolipids and phospholipids were separated using an activated silicic acid column and eluted with $5 \mathrm{ml}$ chloroform, $10 \mathrm{ml}$ acetone, and $5 \mathrm{ml}$ methanol, respectively. Methanol eluates were collected and then dried under nitrogen at $37^{\circ} \mathrm{C}$. After saponification and methylation, the phospholipids were extracted three times with $2 \mathrm{ml} 1: 1(\mathrm{v} / \mathrm{v})$ methyl tert-butyl ether/hexane solution. The fractions were identified by gas chromatography (Agilent GC-6890N, USA), which was equipped with a flame ionization detector and a fused silica capillary column ( $25 \mathrm{~m}$ by $0.2 \mathrm{~mm}$ ) using $\mathrm{H}_{2}$ as the carrier gas. The column temperature was $170{ }^{\circ} \mathrm{C}$ initially and was then increased to $250{ }^{\circ} \mathrm{C}$ at $5{ }^{\circ} \mathrm{C} \mathrm{min}{ }^{-1}$. The resulting FAMEs were analyzed by using the MIDI Sherlock microbial identification system (MIDI, Inc., Newark, DE). Different fatty acids were considered to represent different microorganisms. Selected FAMEs were used as bacterial markers according to the previous studies (Kourtev et al. 2003; Zelles 1997; Zelles et al. 1994; Mbuthia et al. 2015), and included six Gram-positive $\left(\mathrm{Gram}^{+}\right)$bacteria (i14:0, i15:0,a15:0, i16:0, i17:0,

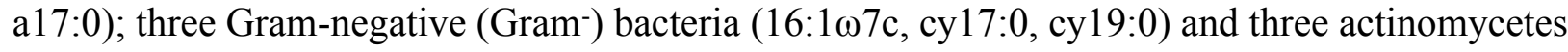
(10Me16:0,10Me17:0, 10Me18:0). The bacterial sums were calculated using the $\mathrm{Gram}^{+}, \mathrm{Gram}^{-}$, and actinomycete markers. According to the previous research (Frostegaård and Bååth 1996; Frostegaård et al. 1993), fungal indicators included two saprophytic fungal biomarkers (18:1 $\omega 9 \mathrm{c}$, $18: 2 \omega 6,9)$ and one mycorrhizal fungi associated biomarker $(16: 1 \omega 5 \mathrm{c})$. The fungal sums were calculated based on the summation of $18: 1 \omega 9 \mathrm{c}$ and 18:2 $\omega 6,9$. The arbuscular mycorrhizal fungi (AMF) biomarker was excluded from fungal summation due to its unique nature in soil function

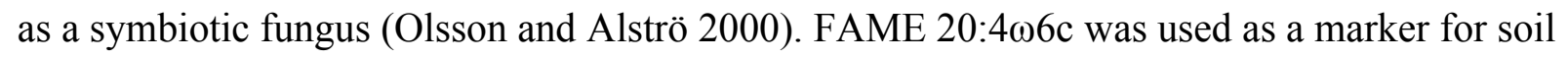
protozoa according to Stromberger et al. (2012). The F:B ratio was calculated by dividing the fungal sum by the bacterial sum, and the $\mathrm{Gram}^{+} / \mathrm{Gram}^{-}$ratio was calculated by dividing the $\mathrm{Gram}^{+}$sum by the Gram sum. The individual peak data for each fatty acid was converted to 
173 molar percentages by dividing the peak area by the fatty acid molecular weight and then by 174 dividing the total molar area of all fatty acids identified in the sample.

\section{Statistical analyses}

All data are expressed as means \pm standard error. Specific differences between

177 monocropping and intercropping treatments were determined by the least significant difference test (LSD, $p<0.05$ ) applied after an analysis of variance (ANOVA). Box plots were graphed by using SigmaPlot 10.0. A principal component analysis (PCA) was conducted by using the CANOCO software (Version 5.0, Microcomputer Power, Ithaca, USA) to determine the differences in soil microbial community structure composition between intercropping and monocropping systems for each sampling date. The soil FAME biomarkers of $\mathrm{Gram}^{+}$bacteria, Gram-bacteria, actinomycetes, saprophytic fungi, mycorrhizal fungi, protozoa, total bacterial sums, fungal/bacterial ratio, and $\mathrm{Gram}^{+} / \mathrm{Gram}^{-}$ratio were considered as indicators. The individual FAMEs transformed by square root were considered to be normally distributed dataset and decreased the coefficient of variation. Correlation analyses among the soil microbial population, enzyme activities, and chemical properties were conducted using the CORR program. The analyses were performed using SAS software (version 8.1).

\section{Results}

\section{Growth and Photosynthetic Pigment Analyses}

As shown in Figure 1, compared to cucumber monoculture, the shoot biomass of cucumber, when intercropped with green garlic, was significantly higher $(P<0.05)$ on days 45 . While the higher root biomass of cucumber was observed in intercropping systems on days 30 and 45 .

Intercropping with green garlic slightly improved chlorophyll a and total carotenoid contents of cucumber, and the effect was enhanced by extending the co-existence time (Figure 2). Only chlorophyll b content of cucumber was significantly increased by intercropping with green garlic on the third sampling time.

\section{Soil chemical properties}

The intercropping treatment significantly affected the chemical properties of both, the bulk as well as the rhizosphere soil (Table 1). In the bulk soil, the organic matter, and the available $\mathrm{N}$ and $\mathrm{K}$ contents were significantly higher $(P<0.05)$ under green garlic-cucumber intercropping than under cucumber monocropping at each sampling date. The available $\mathrm{P}$ content in the soil showed a significant increase $(P<0.05)$ in the intercropping treatment, except at the first sampling date. There were no significant differences in the soil $\mathrm{pH}$ values between the intercropping and monocropping systems. Except for $\mathrm{pH}$ value, other chemical properties were $20 \%-40 \%$ higher in the rhizosphere soil than in the bulk soil on the same sampling date. In the 
208 rhizosphere soil, the available N, P and K contents had significant increases $(P<0.05)$ at each 209 sampling date, when intercropped with green garlic. Compared to monoculture, the green garlic-

210 intercropping system showed significant improvement in the $\mathrm{pH}$ value on the third sampling date.

211 These results indicate that there is a positive effect of intercropping treatment on soil chemical

212 properties which enhanced with prolonged co-existence time.

213

214

215

216

217

218

219

220

221

222

223

224

225

226

227

228

229

230

231

232

233

234

235

236

237

238

239

240

241

242

243

\section{Soil enzyme activities}

The soil enzyme activities varied widely among the cropping systems, sampling dates, and locations (Figure 3). Intercropping with green garlic showed different effects among different enzymes. The soil catalase activity in the bulk soil of the intercropping system was significantly higher $(P<0.05)$ than that of the monocropping system at each sampling date. However, no significant difference in the rhizosphere soil was observed (Figure 3-A and B). The invertase activity in the rhizosphere soil of the intercropping system was significantly higher $(15.87,15.97$, 15.72 glucose $\mathrm{mg} / \mathrm{g}$ ) when compared to monocropping $(13.90,11.29,12.21$ glucose $\mathrm{mg} / \mathrm{g}$ ) on days 15,30 and 45 after interplanting, respectively. Invertase activity was significantly increased by $12 \%$ only on the third sampling date in the bulk soil of intercropping system (Figure 3-C and D). Intercropping significantly increased the urease activity by $26 \%$ in the rhizosphere soil after interplanting on day 15. However, the urease activity in the bulk soil of cucumber showed no significant effect by intercropping with green garlic (Figure 3-E and F). On the first sampling date, there were no significant differences in alkaline phosphatase activities among different treatments. By increasing co-existence time, the alkaline phosphatase activity in the bulk, as well as in the rhizosphere soils, was higher under intercropping than under monocropping (Figure 3-G and $\mathrm{H}$ ).

\section{Culturable soil microorganisms}

Changes in soil microbial densities were shown in Figure 4. The number of culturable bacteria in the bulk soil and actinomycetes in both the bulk and the rhizosphere soils of the intercropping system were significantly higher than those of the monocropping system at each sampling date (Figure 4-A and B and 4-E and F). In contrast, intercropping significantly decreased the densities of culturable fungi by $27 \%, 67 \%$, and $66 \%$ in the bulk soil and $41 \%, 35 \%$, and $61 \%$ in the rhizosphere soil than that under the monocropping system on days 15,30 , and 45 after interplanting, respectively (Figure 4-C and D). Obviously, the differences in the culturable fungi between the intercropping and monocropping systems increased with extended coexistence time.

\section{Microbial community diversity and composition}

The total amount of PLFAs, which is an indicator of the total microbial biomass, was represented by total FAMEs as shown in Figure 5. Intercropping with green garlic significantly increased $(P<0.05)$ the total microbial biomass in both the bulk and the rhizosphere soils 
244

245

246

247

248

249

250

251

252

253

254

255

256

257

258

259

260

261

262

263

264

265

266

267

268

269

270

271

272

273

274

275

276

277

278

279

compared to that of cucumber monoculture. The total microbial biomass in the monocropping system was constantly decreased with increasing co-existence time. Thirty PLFAs with chain lengths from $\mathrm{C} 11$ to $\mathrm{C} 20$ were identified in all the soil samples. However, only 16 PLFAs that were used as biomarkers of specific microbial groups were found in the soils, these are listed in Table $2 \mathrm{a}$ and $2 \mathrm{~b}$. The sum of $\mathrm{Gram}^{+}$and actinomycete bacterial FAMEs were significantly higher under green garlic/cucumber intercropping than under cucumber monocropping in both bulk and rhizosphere soils at all sampling dates. After interplanting, the sum of Gram- bacterial FAMEs showed a significant increase by intercropping with green garlic in both the bulk and rhizosphere soils on days 45 . The marker for AMF (16:1 $155 \mathrm{c})$ was significantly higher under intercropping than under monocropping system. However, the sum of saprophytic fungal FAMEs was lower under intercropping than under monocropping. Moreover, compared to

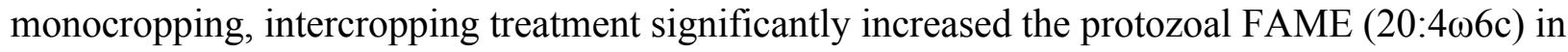
both the bulk and rhizosphere soils.

The relative abundance of indicator FAMEs was shown in Figure 6. Intercropping with green garlic significantly improved the accumulation of $\mathrm{Gram}^{+}$bacteria, mycorrhizal fungi, and total bacteria in bulk and rhizosphere soils. Interestingly, the relative abundance of Grambacteria showed little difference between the monocropping and intercropping systems. In contrast, biomarkers of saprophytic fungal and F:B ratio were more gathered in cucumber monoculture (both bulk and rhizosphere soils).

PCA based on PLFA data showed that intercropping with green garlic distinctly affected the soil microbial community composition when compared to cucumber monoculture (Figure 7). On three different sampling dates, the PC1 of the FAMEs biomarkers accounted for $83.5 \%, 78.6 \%$ and $90.6 \%$ of the variance, and the PC2 accounted for $9.8 \%, 18.8 \%$, and $6.0 \%$ of the variance, respectively. Bulk and rhizosphere soils in cucumber monoculture system showed much greater relative proportions of saprophytic fungal and higher F:B ratio on each sampling date (Figure 7A, B and C). However, the intercropping system showed more differences in different sampling dates between bulk and rhizosphere soils. After interplanting, more total bacteria, AMF and protozoan indicators were found in the rhizosphere soil on days 15. Moreover, the $\mathrm{Gram}^{+}, \mathrm{Gram}^{-}$ actinomycetes, total bacteria, and protozoa FAMEs were clustered together in rhizosphere soil, while greater relative proportions of AMF and $\mathrm{Gram}^{+}$: Gram ${ }^{-}$were found in the bulk soil on days 45 after interplanting. To better understand the relationship between the changes in community composition under different cropping systems and co-existence time, the FAME profiles for each system were analyzed independently on different sampling dates (Figure 7-D and E). The analysis showed a total fungal FAMEs cluster in the monocropping system, while a total bacterial FAMEs cluster in the intercropping system. Additionally, the effect was increasingly more distinct with increasing co-existence time. 
280

281

282

283

284

285

286

287

288

289

290

291

292

293

294

295

296

297

298

299

300

301

302

303

304

305

306

307

308

309

310

311

312

313

314

\section{Correlation analysis}

The correlations among the soil chemical, microbiological, and biochemical parameters were analyzed in the monocropping (Table 3a) and intercropping systems (Table $3 \mathrm{~b}$ ). In the cucumber monoculture system, the activities of soil urease, invertase and alkaline phosphatase were positively correlated with microorganism quantities (bacteria and fungi), total microbial biomass, soil organic matter (SOM), pH value and available nutrient (N, P and $\mathrm{K}$ ) contents. The catalase activity was significantly correlated with only the total microbial biomass. Except for catalase, other enzyme activities were all significantly $(P<0.05)$ or markedly significantly $(P<0.01)$ related to each other. The number of fungi was positively correlated with that of actinomycetes $(\mathrm{r}=0.90, P<0.05)$. The correlation between the soil chemical, microbiological, and biochemical parameters was weakened when cucumber was intercropped with green garlic (Table $3 b)$. The soil urease activity was significantly correlated with total microbial biomass $(\mathrm{r}=$ $0.87, P<0.05)$, available $\mathrm{N}$ contents $(\mathrm{r}=0.95, P<0.01)$ and $\mathrm{SOM}$ contents $(\mathrm{r}=0.84, P<0.05)$. The soil invertase activity was only significantly correlated with available $\mathrm{N}$ contents $(\mathrm{r}=0.88$, $P<0.05)$. The alkaline phosphatase activity was significantly correlated with the number of bacteria $(\mathrm{r}=0.93, P<0.01)$ and actinomycetes $(\mathrm{r}=0.92, P<0.01)$ as well as the available $\mathrm{K}$ contents $(\mathrm{r}=0.90, P<0.05)$. The urease activity was significantly correlated with invertase activity $(\mathrm{r}=0.87, P<0.05)$. However, the number of fungi was negatively correlated with the number of bacteria $(\mathrm{r}=-0.81, P<0.05)$ and actinomycetes $(\mathrm{r}=-0.84, P<0.05)$.

\section{Discussion}

\section{Effect of intercropping on soil microbial structure and diversity}

Soil quality depends on total microbial abundance. The previous studies have verified that the abundance of soil bacteria first decreases and then increases, whereas the abundance of fungi increases over years of continuous cropping (Fu et al. 2017; Jpo et al. 2012). However, soil microbial abundance can be altered by land management practice and cropping systems. According to a few studies, compared to monocropping, intercropping modified the soil microbial community structure more effectively ( $\mathrm{Li}$ and $\mathrm{Wu} 2018$; Li et al. 2010). In the present study, intercropping with green garlic significantly decreased the fungal population, while increased the bacterial and actinomycetes population; similar changes were also found in the rice/watermelon intercropping soil (Ren et al. 2008). However, Zhou et al. (2011) reported that intercropping cucumber with onion or garlic promoted bacterial as well as fungal communities. These differences might be attributed to different allelopathic and antifungal effects between green garlic and garlic. Garlic-cucumber intercropping system also done in our previous study of plastic tunnel (Xiao et al. 2012, 2013), found that intercropping with garlic stimulated number of 
315

316

317

318

319

320

321

322

323

324

325

326

327

328

329

330

331

332

333

334

335

336

337

338

339

340

341

342

343

344

345

346

347

348

349

350

soil bacteria and actinomyces, while inhibited number of fungi, and improved soil enzymes activities. The result is similar to green garlic intercropping with cucumber in present study.

Specific microbial population was altered according to the profiling of microbial FAMEs biomarkers in the present study, meaning that the directional change of soil microbes occurs due to intercropping with green garlic. The sum of $\mathrm{Gram}^{-}$bacteria and AMF population were significantly higher under the intercropping than monocropping system, consequently inducing the relief of continuous cropping obstacle of cucumber. Evidence suggest that Gram- bacteria could effectively degrade the phenolic compounds, which act as the main autotoxins that limit the growth of cucumber in continuous monoculture (Zhang et al 2010; Zhou et al. 2012, 2018). In addition, the AMF population is used as an indicator of soil function and quality in sustainable agricultural systems (Moeskops et al. 2010; Bowles et al. 2014). The 16:1 05 c FAME marker for AMF (Olsson and Alströ 2000) was increased when intercropped with green garlic, indicating that the intercropping system offers a more favorable soil environment for AMF population than does the continuous cucumber monocropping system.

Microbial community composition and structure is also one of the indicators of soil function and quality. Long-term continuous cropping resulted in simplification and imbalance of the microbial structure, which is a critical factor contributing to continuous cropping obstacle (Fu et al. 2017). Many researches suggested that rotational cropping could relieve cropping obstacle by shifting the rhizosphere microbial community (Acosta-Martínez et al. 2017; He et al. 2018). In this study, PCA analysis showed that more bacterial FAMEs biomarkers were accumulated in the intercropped soils (GB and GR), while more fungal FAMEs biomarkers were accumulated in the monoculture soils ( $\mathrm{CB}$ and $\mathrm{CR}$ ). This may be due to the root interactions in the intercropping system and the root exudates released by different plant species. Many studies have confirmed that different organic acid compositions of released root exudates could affect the composition of microbial communities (Xu et al. 2015; Zhou et al. 2018). The reduction of total fungi and F:B ratio in the intercropping system might be associated with the inhibitory effect of garlic root exudates on soil-borne diseases (Khan et al. 2011).

\section{Effect of intercropping on soil enzymes activities}

Except for soil microorganisms, soil enzymes are directly involved in many biochemical processes such as cycling of nutrients, fertilizer use efficiency, etc that are essential for soil quality maintenance ( $\mathrm{Li}$ et al. 2016, 2018). Soil invertase, urease and phosphatases are important hydrolases that play key biochemical roles in the overall process of material and energy conversion in the soil ecosystem (Gu et al. 2009). Soil invertase hydrolyzes sucrose to glucose and fructose, urease catalyzes the hydrolysis of urea, and phosphatase catalyzes the hydrolysis of phosphoric acid to esters and anhydrides (Saha et al. 2008). Previous studies verified that the soil enzyme activities were linked to soil microbial biomass, organic matter content, and nutrient

Peer] reviewing PDF | (2019:02:35074:1:1:NEW 23 May 2019) 
351

352

353

354

355

356

357

358

359

360

361

362

363

364

365

366

367

368

369

370

371

372

373

374

375

376

377

378

379

380

381

382

383

384

385

supply (Makoil and Ndakidemi 2008). Acosta-Martínez et al. (2014) demonstrated that the soil enzyme activities are positively correlated with microbial biomass and protozoan population. Similar results were obtained in our experiment. In addition, greater soil catalase, invertase, urease and alkaline phosphatase activities were exhibited under the green garlic-cucumber intercropping system, which was in accordance with other studies conducted on garlic-based intercropping systems (Xiao et al. 2012; Wang et al. 2014; Liu et al. 2014; Khan et al. 2015).

\section{Effect of intercropping on soil nutrient}

Different tillage and cropping systems can transform the soil fertility status, thereby affecting crop yield and quality. Legume-based intercropping, owing to its biological fixation of $\mathrm{N}$, was considered as a popular practice in traditional agriculture. Furthermore, the availability and mobilization of $\mathrm{P}, \mathrm{Fe}$ and $\mathrm{Zn}$ in the soil were enhanced (Li et al. 2013; Scalise et al. 2015). Similarly, our study demonstrated that intercropping with green garlic led to higher N, P and K availability. Numerous studies have suggested that the modification of soil nutrient availability under intercropping conditions affects direct root-mediated and indirect microbe-mediated processes ( $\mathrm{Li}$ et al. 2013; Xue et al. 2016; Tian et al. 2018). In this study, we observed that the increase of soil biological community quantities and diversities enhanced advanced soil nutrients availability. The interactions between cucumber and green garlic roots should be further investigated in future studies.

\section{Effect of intercropping on growth and photosynthetic pigment of cucumber} Continuous mono-cropping of the same crop in the same land can cause a reduction in crop growth and photosynthetic capacity, which was demonstrated in cucumber (Yu et al. 2000; Zhou et al. 2012). Chlorophyll, the main photosynthetic pigment, plays an important role in determining the photosynthetic rate and dry matter production (Dai et al. 2013). Zhou et al. (2007) found that plant biomass and chlorophyll content of the tested tomato and hot pepper was increased by garlic root exudates. In the present study, intercropping with green garlic improved the shoot and root biomass and chlorophyll b content of cucumber, which might be due to stimulation of green garlic root exudates. The same phenomenon was also found in intercropping of garlic with pepper (Ahmad et al. 2013), eggplant (Wang et al. 2015) and tomato (Liu et al. 2014).

\section{Conclusion}

The greater shoot biomass of cucumber was observed under the intercropping system than the monocropping system one month after co-existence. Soil analysis confirmed that intercropping with green garlic alleviated the continuous cropping obstacle of cucumber by improving the soil microbial community diversity and composition, as well as soil enzyme activities and nutrient availability. Further studies that focus on underground root interactions and morphogenesis, and 
386

387

388

389

390

391

392

393

394

395

396

397

398

399

400

401

402

403

404

405

406

407

408

409

410

411

412

413

414

415

416

417

418

419

persistent effect of green garlic-based intercropping system should be conducted.

\section{Acknowledgments}

We express our sincere thanks to Muhammad Azam Khan (PMAS-Arid Agriculture University, Rawalpindi, Pakistan) for English language revision and valuable suggestions to the revision of the manuscript.

\section{References}

Abdel-Monaim MF, Abo-Elyousr KAM. 2012. Effect of preceding and intercropping crops on suppression of lentil damping-off and root rot disease in New Valley- Egypt. Crop Prot. 32: 41-46.

Acosta-Martínez V, Cotton J. 2017. Lasting effects of soil health improvements with management changes in cotton-based cropping systems in a sandy soil. Biol Fert Soils. 53: 533-546.

Acosta-Martínez V, Cotton J, Gardner T, Moore-Kucera J, Zak J, Wester D, Cox S. 2014. Predominant bacterial and fungal assemblages in agricultural soils during a record drought/heat wave and linkages to enzyme activities of biogeochemical cycling. Appl Soil Ecol. 84: 69-82.

Ahmad I, Cheng ZH, Meng HW, Liu TJ, Wu CN, Khan MA, Wasila H, Khan AR. 2013. Effect of intercropped garlic (Allium Sativum) on chlorophyll contents, photosynthesis and antioxidant enzymes in pepper. Pak. J. Bot. 45(6): 1889-1896.

Arnon DI. 1949. Copper enzymes in isolated chloroplasts. Polyphenoloxidase in Beta vulgaris. Plan Physiol. 24: 1-15.

Balota EL, Kanashiro M, Colozzi A, Andrade DS, Dick RP. 2004. Soil enzyme activities under long-term tillage and crop rotation systems in subtropical agroecosystems. Braz J Microbiol. 35: 300-306.

Bowles TM, Acosta-Martínez V, Calderón F, Jackson LE. 2014. Soil enzyme activities, microbial communities, and carbon and nitrogen availability in organic agroecosystems across an intensively-managed agricultural landscape. Soil Biol Biochem. 68: 252-262.

Cotton J, Acosta-Martínez V, Moore-Kucera J, Burow G. 2013. Early changes due to sorghum biofuel cropping systems in soil microbial communities and metabolic functioning. Biol Fert Soils. 49: 403-413.

Dai CC, Chen Y, Wang XX, Li PD. 2013. Effects of intercropping of peanut with the medicinal plant Atractylodeslancea on soil microecology and peanut yield in subtropical China. Agroforest Sys. 87: 417-426.

El-Tarabily KA, Hardy GESJ, Sivasithamparam K, KurtbÖke ID. 1996. Microbiological 
420

421

422

423

424

425

426

427

428

429

430

431

432

433

434

435

436

437

438

439

440

441

442

443

444

445

446

447

448

449

450

451

452

453

454

455

differences between limed and unlimed soils and their relationship with cavity spot disease of carrots (Daucus carota L.) caused by Pythium coloratum in Western Australia. Plant Soil. 183: 279-290.

Frostegaård A, Bååth E, Tunlid A. 1993. Shifts in the structure of soil microbial communities in limed forests as revealed by phospholipid fatty acid analysis. Soil Biol Biochem. 25(7): 23730.

Frostegaård A, Bååth E. 1996. The use of phospholipid fatty acid analysis to estimate bacterial and fungal biomass in soil. Biol Fert Soils. 22: 59-65.

Gu Y, Wang P, Kong CH. 2009. Urease, invertase, dehydrogenase and polyphenoloxidase activities in paddy soil influenced by allelopathic rice variety. Eur J Soil Biol. 45: 436-441.

Hamzei J, Seyyedi M. 2016. Energy use and input-output costs for sunflower production in sole and intercropping with soybean under different tillage systems. Soil Till Res. 157: 73-82.

He Y, Ding N, Shi JC, Wu M, Liao H, Xu JM. 2013. Profiling of microbial PLFAs: Implications for interspecific interactions due to intercropping which increase phosphorus uptake in phosphorus limited acidic soils. Soil Biol Biochem. 57: 625-634.

Johnson JL, Temple KL. 1964. Some variables affecting the measurement of catalase activity in soil. Soil Sci Soc Am J. 28: 207-209.

Khan MA, Cheng ZH, Khan AR, Rana SJ, Ghazanfar B. 2015. Pepper-Garlic intercropping system improves soil biology and nutrient status in Plastic Tunnel. Int J Agric Biol. 17: 869880.

Khan MA, Cheng ZH, Xiao XM, Khan AR, Ahmed SS. 2011.Ultrastructural studies of the inhibition effect against Phytophthoracapsici of root exudates collected from two garlic cultivars along with their qualitative analysis. Crop Prot. 30: 1149-1155.

Kourtev PS, Ehrenfeld JG, Häggblom M. 2003. Experimental analysis of the effect of exotic and native plant species on the structure and function of soil microbial communities. Soil Biol Biochem. 35: 895-905.

Latif MA, Mehuys GR, Mackenzie AF, Alli I, Faris MA. 1992. Effects of legumes on soil physical quality in a maize crop. Plant Soil. 140: 15-23.

Li CH, Fultz LM, Moore-Kucera J, Acosta-Martínez V, Kakarla M, Weindorf DC. 2018. Soil microbial community restoration in Conservation Reserve Program semi-arid grasslands. Soil Biol Biochem. 118: 166-177.

Li HG, Shen JB, Zhang FS, Marschner P, Cawthray G, Rengel Z. 2010. Phosphorus uptake and rhizosphere properties of intercropped and monocropped maize, faba bean, and white lupin in acidic soil. Biol Fert Soils. 46: 79-91.

Li HG, Zhang FS, Rengel Z, Shen JB. 2013. Rhizosphere properties in monocropping and intercropping systems between faba bean (Vicia faba L.) and maize (Zea mays L.) grown in 
456

457

458

459

460

461

462

463

464

465

466

467

468

469

470

471

472

473

474

475

476

477

478

479

480

481

482

483

484

485

486

487

488

489

490

491

a calcareous soil. Crop Pasture Sci. 64: 976-984.

Li J, Lin WF, Zhou LJ. 2016. Effects of long-term intercropping coffee on rubber soil nutrients and soil enzymes. Southwest China J. Agric. Sci. 29: 1371-1374.

Li QS, Wu LK, Chen J, Khan MA, Luo XM, Lin WX. 2016. Biochemical and microbial properties of rhizospheres under maize/peanut intercropping. J Integr Agr. 15(1): 101-110.

Li S, Wu FZ. 2018. Diversity and co-occurrence patterns of soil bacterial and fungal communities in seven intercropping systems. Front. Microbiol. 9: 1-13.

Li XP, Mu YH, Cheng YB, Liu XG, Nian H. 2013. Effects of intercropping sugarcane and soybean on growth, rhizosphere soil microbes, nitrogen and phosphorus availability.Acta Physiol Plant. 35: 1113-1119.

Liu TJ, Cheng ZH, Meng HW, Ahmad I, Zhao HL. 2014. Growth, yield and quality of spring tomato and physicochemical properties of medium in a tomato/garlic intercropping system under plastic tunnel organic medium cultivation. Sci Hortic. 170: 159-168.

Makoil JHJR, Ndakidemi PA. 2008. Selected soil enzymes: examples of their potential roles in the ecosystem. Afr J Biotechnol. 7: 181-191.

Mbuthia LW, Acosta-Martínez V, DeBryun J, Schaeffer S, Tyler D, Odoi E, Mpheshea M, Walker F, Eash N. 2015. Long term tillage, cover crop, and fertilization effects on microbial community structure, activity: Implications for soil quality. Soil Biol Biochem. 89: 24-34.

Moeskops B, Sukristiyonubowob, Buchan D, Sleutel S, Herawaty L, Husen E. 2010. Soil microbial communities and activities under intensive organic and conventional vegetable farming in West Java, Indonesia. Appl Soil Ecol. 45: 112-120.

Olsson S, Alströ S. 2000. Characterisation of bacteria in soils under barley monoculture and crop rotation. Soil Biol Biochem. 32: 1443-1451.

Ren LX, Su SM, Yang XM, Xu YC, Huang QW, Shen QR. 2008. Intercropping with aerobic rice suppressed Fusarium wilt in watermelon. Soil Biol Biochem. 40(3): 834-844.

Saha S, Prakash V, Kundu S, Kumar N, Mina BL. 2008. Soil enzymatic activity as affected by long term application of farm yard manure and mineral fertilizer under a rainfed soybeanwheat system in N-W Himalaya. Eur J Soil Biol. 44: 309-315.

Scalise A, Tortorella D, Pristeri A, Petrovičová, Gelsomino A, Lindström K, Monti M. 2015. Legume-barley intercropping stimulates soil $\mathrm{N}$ supply and crop yield in the succeeding durum wheat in a rotation under rainfed conditions. Soil Biol. Biochem. 89: 150-161.

Stromberger ME, Keith AM, Schimdt O, 2012. Distinct microbial and faunal communities and translocated carbon in Lumbricusterrestrisdrilospheres. Soil Biol. Biochem. 46: 155-162.

Tabatabai MA. 1994. Soil enzymes. In Weaver RW, Angle JS, Bottomley PS. Methods of soil analysis, Part 2. Microbiological and Biochemical Properties. Soil Science Society of America, Madison, pp. 775-833. 
492 TianXF, Li CL, Zhang M, Li T, Lu YY, Liu LF. 2018. Controlled release urea improved crop

493

494

495

496

497

498

499

500

501

502

503

504

505

506

507

508

509

510

511

512

513

514

515

516

517

518

519

520

521

522

523

524

525

526

527 yields and mitigated nitrate leaching under cotton-garlic intercropping system in a 4-year field trial. Soil Till Res. 175: 158-167.

Wahbi S, Prin Y, Thioulouse J, Sanguin H, Baudoin E, Maghraoui T, Oufdou K, Roux CL, Galiana A, Hafidi M, Duponnois R. 2016. Impact of wheat/faba bean mixed cropping or rotation systems on soil microbial functionalities. Front. Plant Sci. 7: 1-9.

Wang MY, Wu CN, Cheng ZH, Meng HW, Zhang MR, Zhang HJ. 2014. Soil chemical property changes in eggplant/garlic relay intercropping systems under continuous cropping. PloS ONE 9(10): e111040.

Wang MY, Wu CN, Cheng ZH, Meng HW. 2015. Growth and physiological changes in continuously cropped eggplant (Solanum melongena L.) upon relay intercropping with garlic (Allium sativum L.). Front Plant Sci. 6: 1-11.

Wu X, Wu FZ, Zhou XG, Fu XP, Tao Y, Xu WH, Pan K, Liu SW. 2016. Effects of intercropping with potato onion on the growth of tomato and rhizosphere alkaline phosphatase genes diversity. Front Plant Sci. 7: 1-13.

Xiao XM, Cheng ZH, Meng HW, Khan MA, Li HZ, Dong YX. 2013. Intercropping of green garlic (Allium sativum L.) induces nutrient concentration changes in the soil and plants in continuously cropped cucumber (Cucumis sativus L.) in a plastic tunnel. PloS ONE.8(4): e62173.

Xiao XM, Cheng ZH, Meng HW, Khan MA, Li HZ. 2012. Intercropping with garlic alleviated continuous cropping obstacle of cucumber in plastic tunnel. Acta Agr Sc and B-S P. 62 (8): 696-705.

Xu WH, Liu D, Wu FZ, Liu SW. 2015. Root exudates of wheat are involved in suppression of Fusarium wilt in watermelon in watermelon-wheat companion cropping. Eur J Plant Pathol. 141: 209-216.

Xue YF, Xia HY, Christie P, Zhang Z, Li L, Tang CX. 2016. Crop acquisition of phosphorus, iron and zinc from soil in cereal/legume intercropping systems: a critical review. Ann Bot. 117: 363-377.

Yao HY, Jiao XD, Wu FZ. 2006. Effects of continuous cucumber cropping and alternative rotations under protected cultivation on soil microbial community diversity. Plant Soil. 284: 195-203.

Yu JQ, Shou SY, Qian YR, Zhu ZZ, Hu WH. 2000. Autotoxic potential of cucurbit crops. Plant Soil. 223: 147-151.

Zelles L, Bai QY, Ma RX, Rackwitz R, Winter K, Beese F. 1994. Microbial biomass, metabolic activity and nutritional status determined from fatty acid patterns and poly-hydroxybutyrate in agriculturally-managed soils. Soil Biol Biochem. 26: 439-446. 
528 Zelles L. 1997. Phospholipid fatty acid profiles in selected members of soil microbial 529 communities. Chemosphere. 35: 275-294.

530 Zhang ZY, Pan LP, Li HH. 2010. Isolation, identification and characterization of soil microbes 531 which degrade phenolic allelochemicals. J Appl Microbiol. 108: 1839-1849.

532 Zhao J, Ni T, Li J, Lu Q, Fang ZY, Huang QW, Zhang RF, Li R, Shen B, Shen QR. 2016.

533 Effects of organic-inorganic compound fertilizer with reduced chemical fertilizer

534 application on crop yields, soil biological activity and bacterial community structure in a 535 rice-wheat cropping system. Appl Soil Ecol. 99: 1-12.

536 Zhou YL, Cheng ZH, Meng HW. 2007. Allelopathy of garlic root exudates on different receiver 537 vegetables. Chinese J Appl Ecol. 18(1): 81-86.

538 Zhou XG, Gao DM, Liu J, Qiao PL, Zhou XL, Lu HB, Wu X, Liu D, Jin X, Wu FZ. 2014.

539 Changes in rhizosphere soil microbial communities in a continuously monocropped

$540 \quad$ cucumber (Cucumis sativus L.) system. Eur J Soil Biol. 60: 1-8.

541 Zhou XG, Yu GB, Wu FZ. 2011. Effects of intercropping cucumber with onion or garlic on soil 542 enzyme activities, microbial communities and cucumber yield. Eur J Soil Biol. 47: 279-287. 543 Zhou XG, Yu GB, Wu FZ. 2012. Soil phenolics in a continuously mono-cropped cucumber

$544 \quad$ (Cucumis sativus L.) system and their effects on cucumber seedling growth and soil 545 microbial communities. Eur J Soil Sci. 63: 332-340.

546 Zhou XG, Zhang JH, Pan DD, Ge X, Jin X, Chen SC, Wu FZ. 2018. p-Coumaric can alter the 547 composition of cucumber rhizosphere microbial communities and induce negative plant548 microbial interactions. Biol Fert Soils. 54: 363-372.

549 
Figure 1

Effect of intercropping with green garlic on cucumber shoot and root biomass after interplanting on days 15, 30 and 45.

MC-cucumber monoculture; IC-cucumber intercropping with green garlic. Data are means \pm standard error of $n=3$. For each sample date, columns with same letters are not significantly different at the $5 \%$ level.

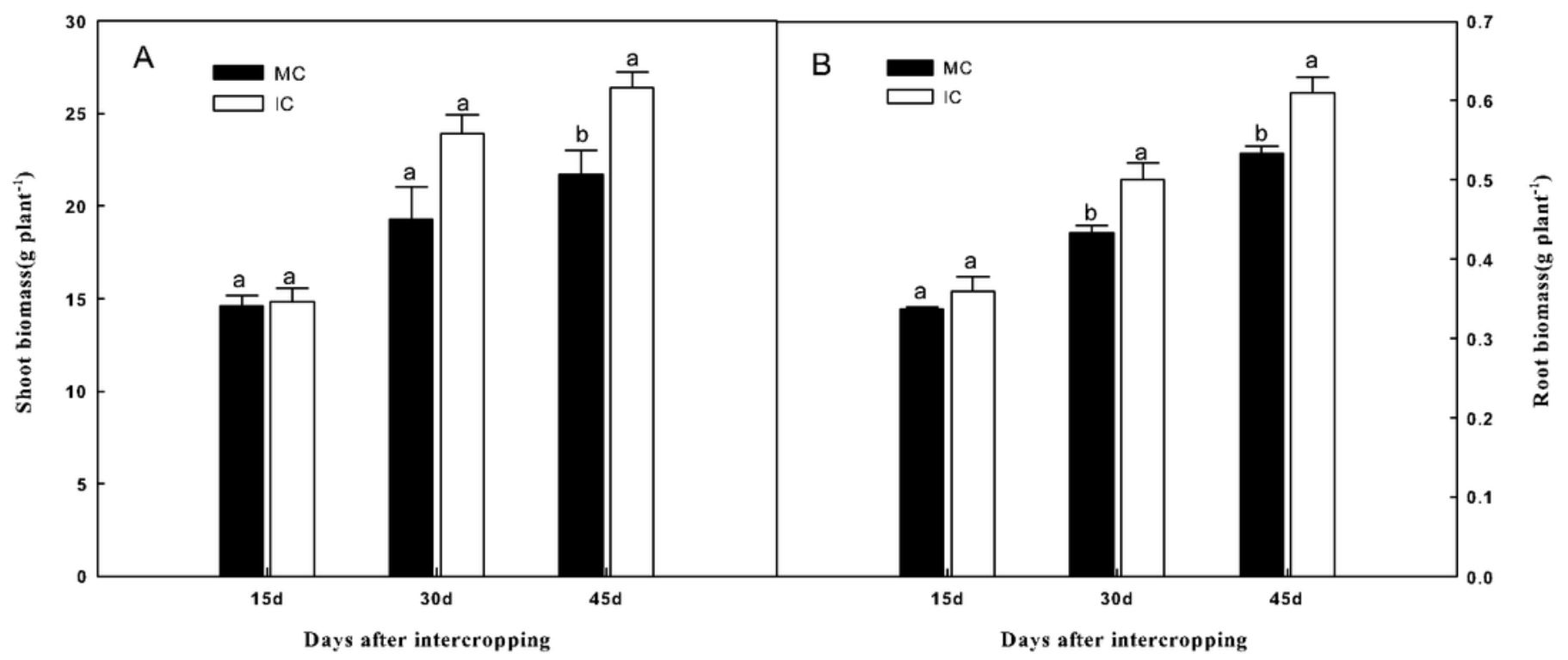




\section{Figure 2}

Effect of intercropping with green garlic on the cucumber chlorophyll a, chlorophyll b and carotenoids after interplanting on days 15, 30 and 45.

MC-cucumber monoculture; IC-cucumber intercropping with green garlic. Data are means \pm standard error of $\mathrm{n}=3$. For each sample date, columns with same letters are not significantly different at the $5 \%$ level.
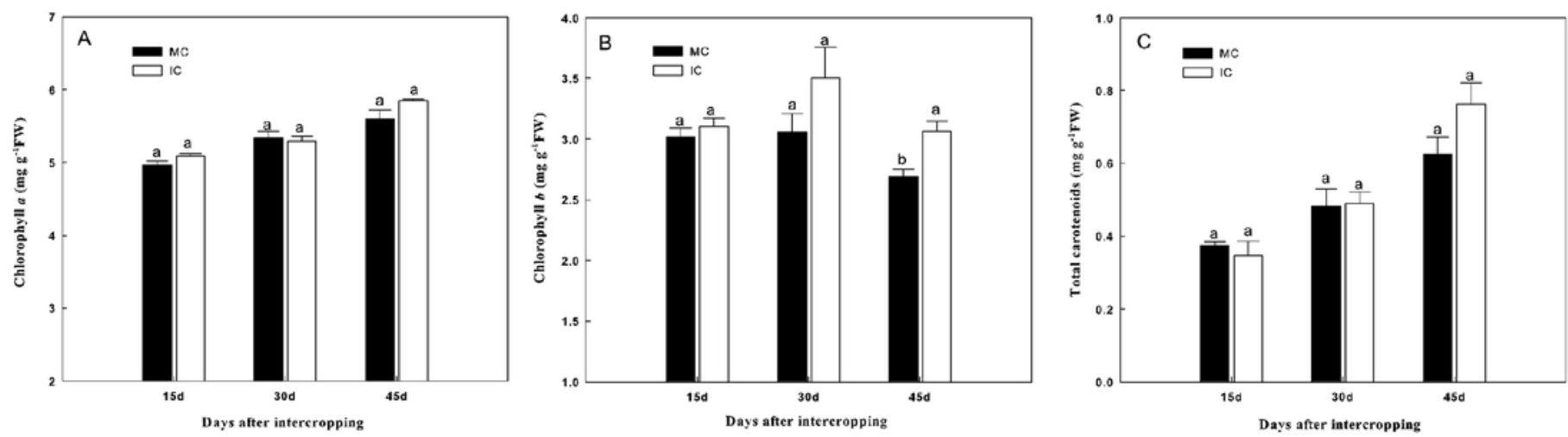


\section{Figure 3}

Effects of intercropping with green garlic on the activities of soil catalase, invertase, urease and alkaline phosphatase in the rhizosphere and bulk soils of cucumber.

Samples were collected after interplanting on days 15, 30 and 45. CB-bulk soil from cucumber monocropping; GB-bulk soil from green garlic intercropping with cucumber; CRrhizosphere soil from cucumber monocropping; and GR-rhizosphere soil from green garlic intercropping with cucumber. Data are mean \pm standard error of $n=3$. For each sample date, lines with same letters are not significantly different at the $5 \%$ level. 


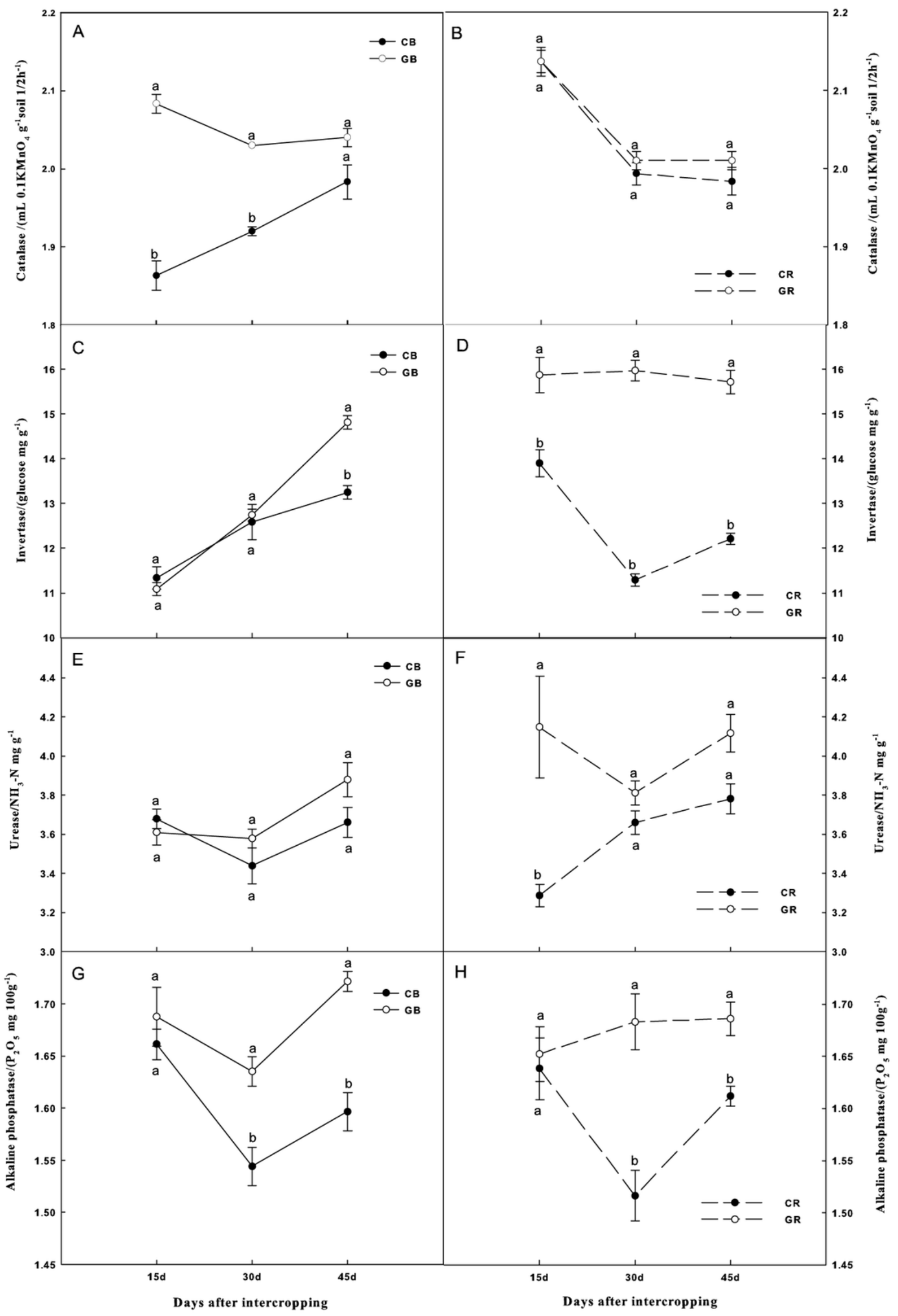

Peer) reviewing PDF | (2019:02:35074:1:1:NEW 23 May 2019) 


\section{Figure 4}

Effects of intercropping with green garlic on the number of bacteria, fungi and actinomycetes in the rhizosphere and bulk soils of cucumber.

Samples were collected after interplanting on days 15, 30 and 45. CB-bulk soil from cucumber monocropping; GB-bulk soil from green garlic intercropping with cucumber; CRrhizosphere soil from cucumber monocropping; and GR-rhizosphere soil from green garlic intercropping with cucumber. Data are mean \pm standard error of $n=3$. For each sample date, lines with same letters are not significantly different at the $5 \%$ level. 


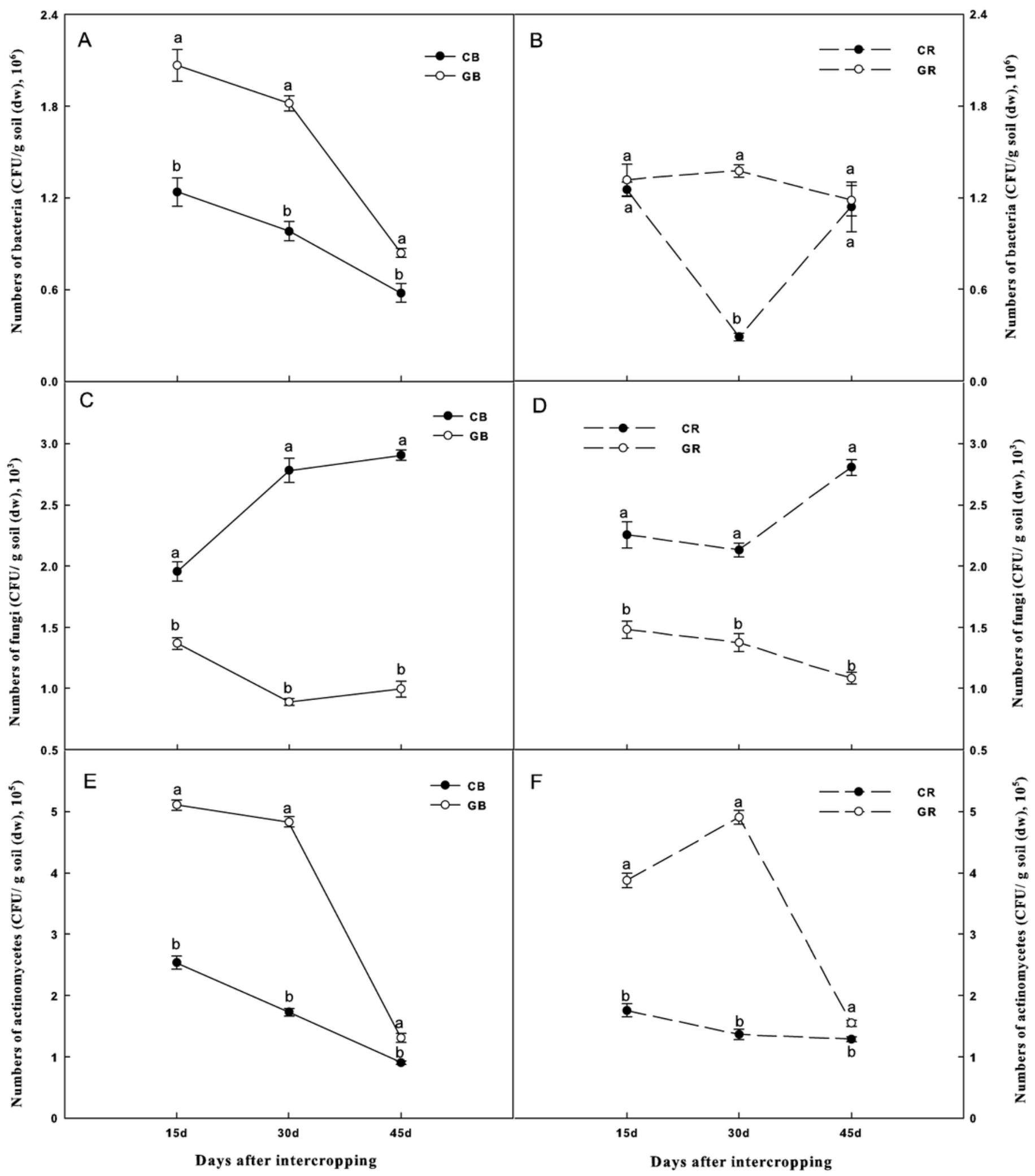




\section{Figure 5}

Total fatty acid methyl esters (FAMEs), (moles\%) in the rhizosphere and bulk soils of cucumber under intercropping and monocropping systems on different sampling dates.

Samples were collected after interplanting on days 15, 30 and 45. CB-bulk soil from cucumber monocropping; GB-bulk soil from green garlic intercropping with cucumber; CRrhizosphere soil from cucumber monocropping; and GR-rhizosphere soil from green garlic intercropping with cucumber. Data are mean \pm standard error of $n=3$. For each sample date, lines with same letters are not significantly different at the $5 \%$ level.

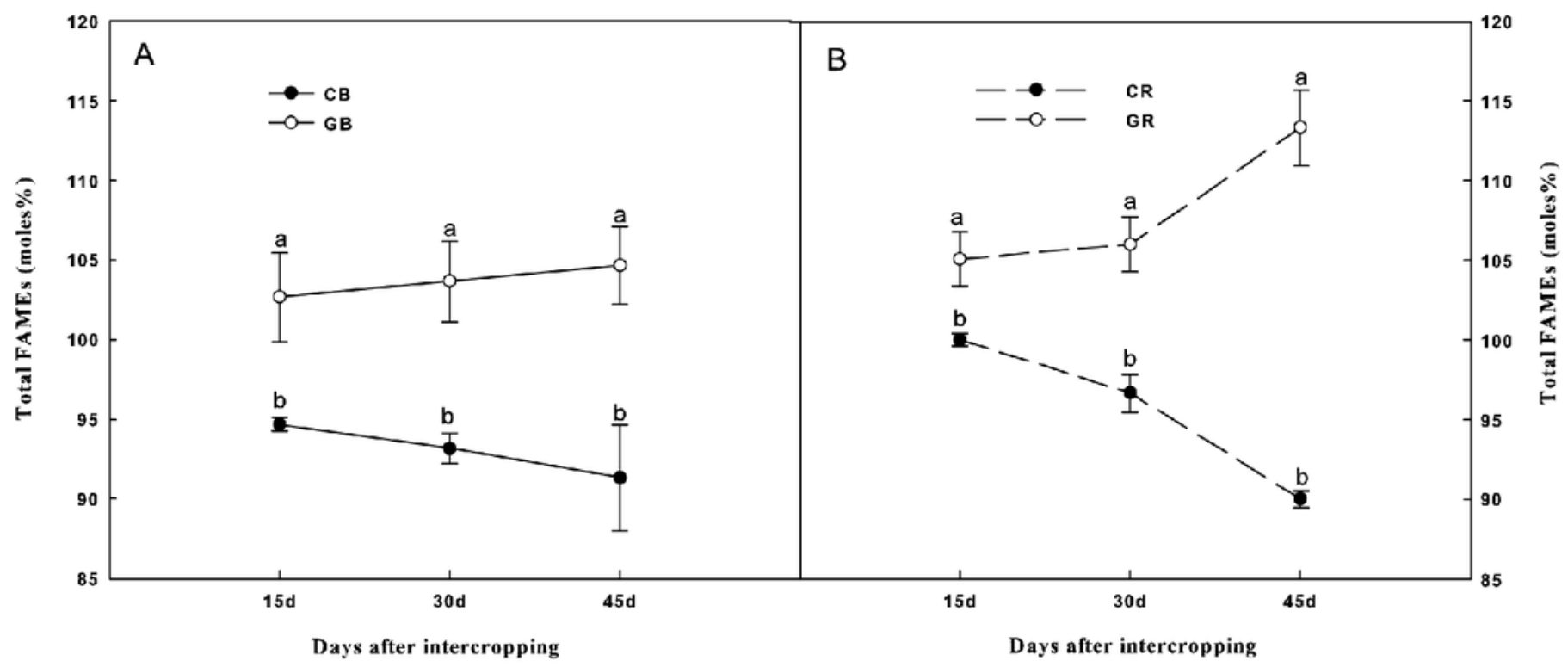




\section{Figure 6}

Box plots of relative abundance of indicator FAMEs in the rhizosphere and bulk soils of cucumber under intercropping and monocropping systems.

Each group is composed of one or more FAMEs and is associated with particular taxon (see methods). The horizontal line in the box was the median, and the upper and lower "hinges" are the first and third quartiles, respectively. The upper and lower "whiskers" extend to the highest or the lowest value within 1.5 times the inter-quartile range (the distance between the first and third quartiles). The A, B, C, D, E, F, G, H and I in the box represent indicator Gram-positive bacteria, saprophytic fungi, total bacterial sums, Gram-negative bacteria, mycorrhizal fungi, fungal/bacterial ratio, actinomycetes, protozoa and $\mathrm{Gram}^{+}$/ Gram ratio. CBbulk soil from cucumber monocropping; GB-bulk soil from green garlic intercropping with cucumber; CR-rhizosphere soil from cucumber monocropping; and GR-rhizosphere soil from green garlic intercropping with cucumber. Data are mean \pm standard error of $n=9$ (three sample dates of three replications for every sample date). For each sample date, boxes with same letters are not significantly different at the $5 \%$ level. 


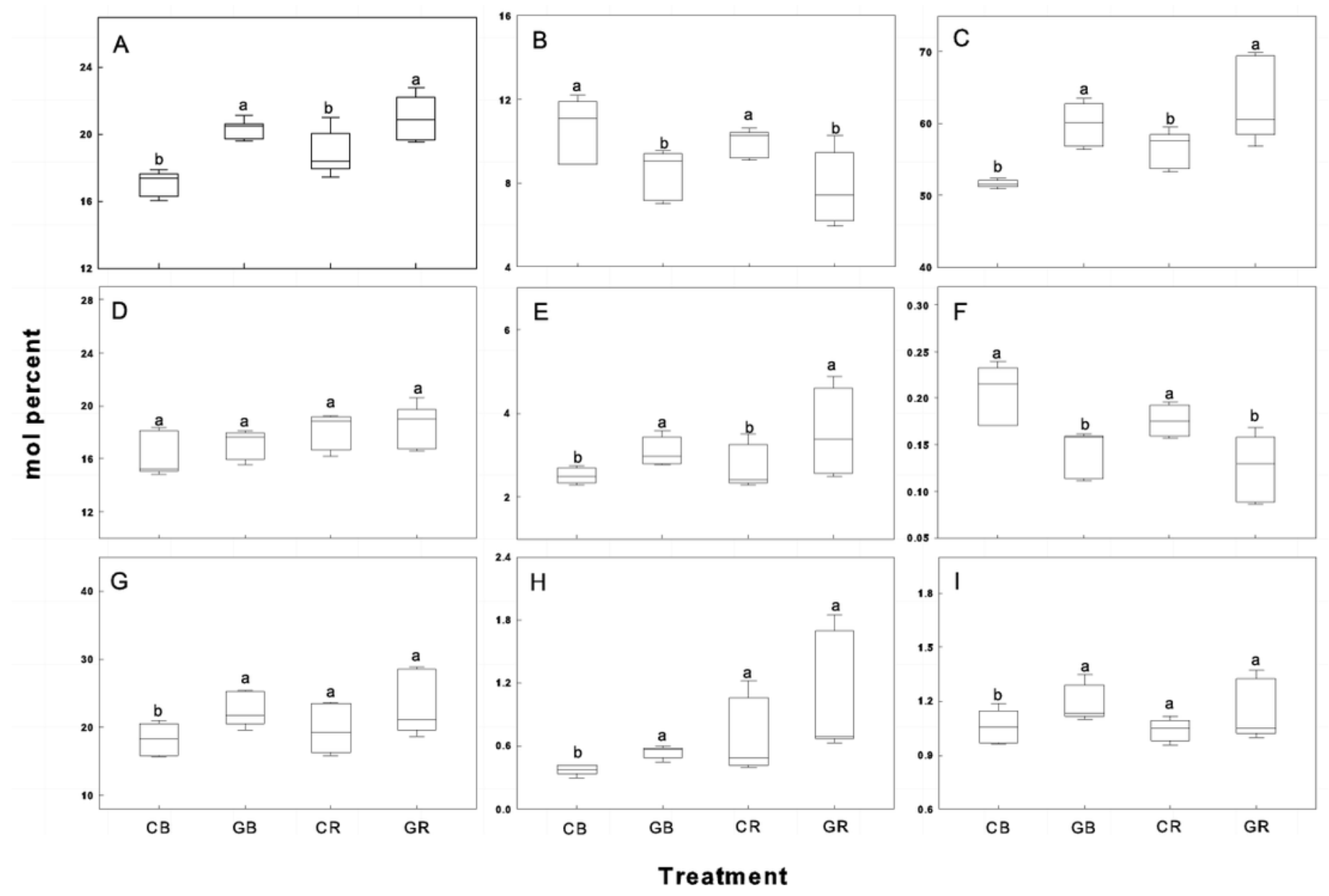




\section{Figure 7}

Microbial community structure according to FAMEs biomarkers $\left(\mathrm{G}^{+}, \mathrm{G}\right.$, actinomycetes, protozoa, AMF, total bacteria, total fungi, fungal: bacterial and $\mathrm{G}^{+}: \mathrm{G}^{-}$) comparing different treatments during each sampling date

The bacterial biomarkers identified included six Gram positive $\left(\mathrm{G}^{+}\right)$bacteria (i14:0, i15:0, a15:0, i16:0, i17:0, a17:0); three Gram negative (G) bacteria (cy17:0, cy19:0, 16:1w7c) and three actinomycetes (10Me16:0, 10Me17:0,10Me18:0). The fungal markers included two

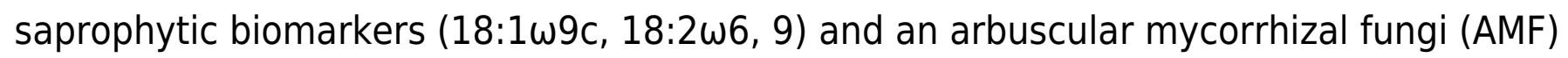
associated biomarker $(16: 1 \omega 5 c)$. The total fungal sum was calculated based on the

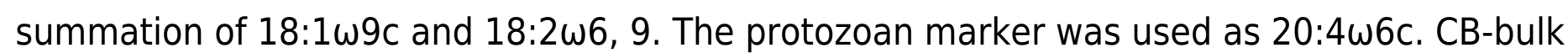
soil from cucumber monocropping; GB-bulk soil from green garlic intercropping with cucumber; CR-rhizosphere soil from cucumber monocropping; GR-rhizosphere soil from green garlic intercropping with cucumber; and first, second and third sampling after interplanting on days 15, 30 and 45. Data are mean \pm standard error of $n=3$. 

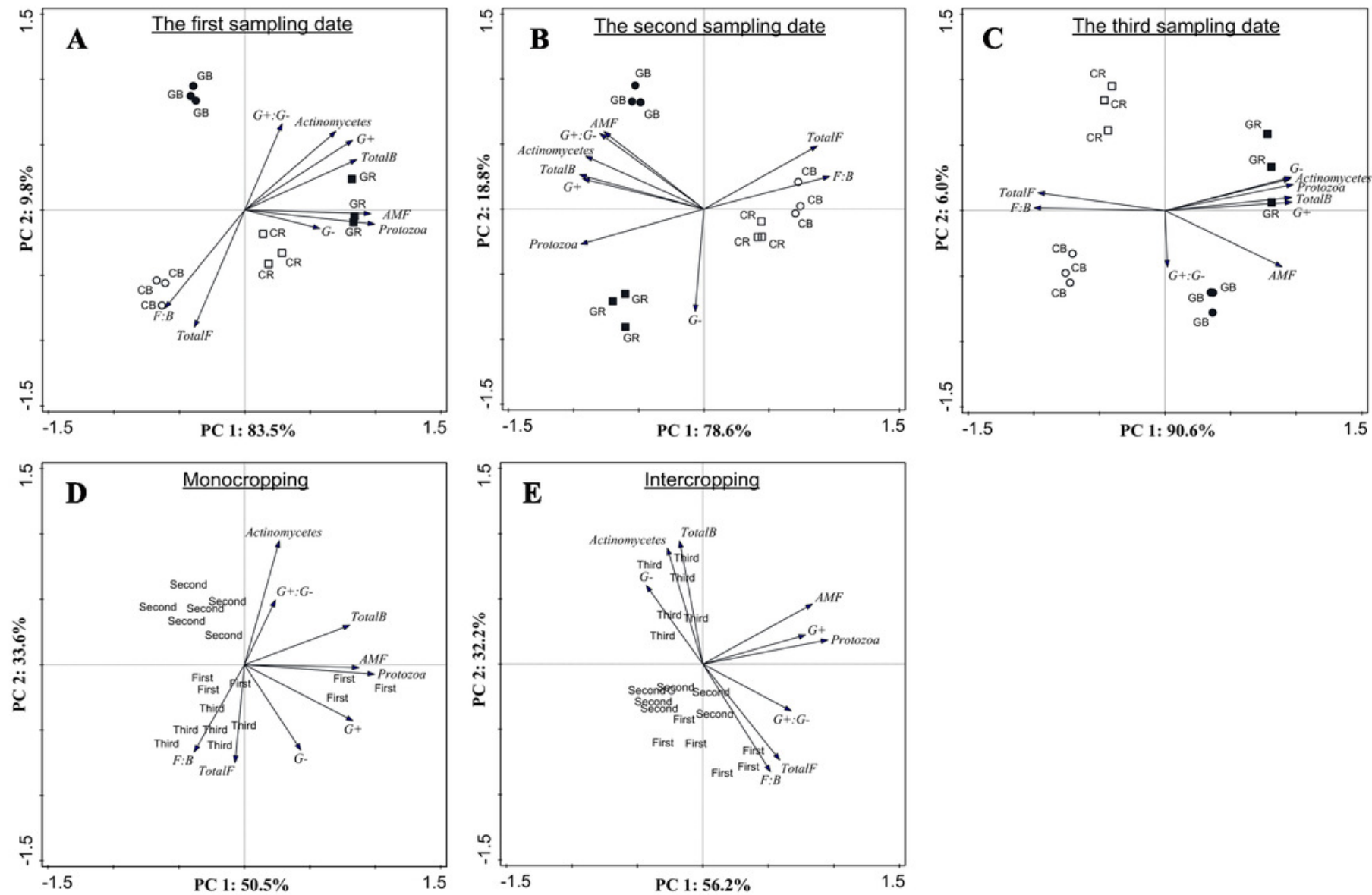


\section{Table $\mathbf{1}$ (on next page)}

Soil chemical properties under intercropping and monocropping systems for different sampling dates

CB-bulk soil from cucumber monocropping; GB-bulk soil from green garlic intercropping with cucumber; CR-rhizosphere soil from cucumber monocropping; GR-rhizosphere soil from green garlic intercropping with cucumber. Data are means \pm standard error of $n=3$. Values followed by the same letter are not significantly different at the $5 \%$ level. 
1 Table 1. Soil chemical properties under intercropping and monocropping systems for different sampling dates

\begin{tabular}{|c|c|c|c|c|c|c|}
\hline $\begin{array}{l}\text { Days after } \\
\text { interplantation }\end{array}$ & Treatments & $\begin{array}{l}\text { Organic matter } \\
\left(\mathrm{g} \cdot \mathrm{kg}^{-1}\right)\end{array}$ & $\begin{array}{c}\text { Available N } \\
\left(\mathrm{mg} \cdot \mathrm{kg}^{-1}\right)\end{array}$ & $\begin{array}{c}\text { Available P } \\
\left(\mathrm{mg} \cdot \mathrm{kg}^{-1}\right)\end{array}$ & $\begin{array}{c}\text { Available K } \\
\left(\mathrm{mg} \cdot \mathrm{kg}^{-1}\right)\end{array}$ & $\begin{array}{c}\mathrm{pH} \text { value } \\
(1: 1 \text { soil : water })\end{array}$ \\
\hline \multirow[t]{4}{*}{15} & $\mathrm{CB}$ & $25.96 \pm 0.18 b$ & $125.4 \pm 2.9 \mathrm{~b}$ & $180.5 \pm 1.2 \mathrm{a}$ & $266.3 \pm 1.4 \mathrm{~b}$ & $7.51 \pm 0.01 \mathrm{a}$ \\
\hline & GB & $27.95 \pm 0.23 \mathrm{a}$ & $145.8 \pm 2.9 \mathrm{a}$ & $179.4 \pm 4.8 \mathrm{a}$ & $290.0 \pm 2.5 \mathrm{a}$ & $7.50 \pm 0.01 \mathrm{a}$ \\
\hline & $\mathrm{CR}$ & $27.92 \pm 0.18 \mathrm{a}$ & $145.8 \pm 2.9 \mathrm{~b}$ & $192.6 \pm 0.9 \mathrm{~b}$ & $275.6 \pm 2.2 b$ & $7.44 \pm 0.01 \mathrm{a}$ \\
\hline & GR & $28.48 \pm 0.18 \mathrm{a}$ & $169.2 \pm 2.9 \mathrm{a}$ & $200.9 \pm 2.7 \mathrm{a}$ & $315.4 \pm 2.6 \mathrm{a}$ & $7.46 \pm 0.01 \mathrm{a}$ \\
\hline \multirow[t]{4}{*}{30} & $\mathrm{CB}$ & $26.03 \pm 0.16 b$ & $107.9 \pm 2.9 b$ & $189.4 \pm 4.2 b$ & $285.1 \pm 5.9 \mathrm{~b}$ & $7.49 \pm 0.02 \mathrm{a}$ \\
\hline & GB & $28.13 \pm 0.18 \mathrm{a}$ & $137.1 \pm 2.9 \mathrm{a}$ & $203.5 \pm 2.7 \mathrm{a}$ & $427.9 \pm 4.6 \mathrm{a}$ & $7.52 \pm 0.01 \mathrm{a}$ \\
\hline & $\mathrm{CR}$ & $27.74 \pm 0.23 b$ & $131.3 \pm 5.1 b$ & $203.9 \pm 0.6 b$ & $294.4 \pm 33.2 b$ & $7.43 \pm 0.03 \mathrm{a}$ \\
\hline & GR & $29.92 \pm 0.10 \mathrm{a}$ & $172.1 \pm 5.8 \mathrm{a}$ & $216.2 \pm 0.7 \mathrm{a}$ & $431.8 \pm 6.0 \mathrm{a}$ & $7.47 \pm 0.01 \mathrm{a}$ \\
\hline \multirow[t]{4}{*}{45} & $\mathrm{CB}$ & $25.98 \pm 0.13 b$ & $110.8 \pm 5.8 b$ & $185.8 \pm 2.8 b$ & $341.9 \pm 0.6 \mathrm{~b}$ & $7.48 \pm 0.01 \mathrm{a}$ \\
\hline & GB & $29.28 \pm 0.14 \mathrm{a}$ & $142.9 \pm 2.9 \mathrm{a}$ & $214.0 \pm 2.0 \mathrm{a}$ & $498.6 \pm 2.8 \mathrm{a}$ & $7.51 \pm 0.02 \mathrm{a}$ \\
\hline & $\mathrm{CR}$ & $28.02 \pm 0.14 b$ & $137.1 \pm 2.9 b$ & $197.2 \pm 1.5 b$ & $366.5 \pm 2.0 \mathrm{~b}$ & $7.42 \pm 0.01 b$ \\
\hline & GR & $30.30 \pm 0.17 \mathrm{a}$ & $175.0 \pm 5.1 \mathrm{a}$ & $223.3 \pm 1.1 \mathrm{a}$ & $521.9 \pm 2.3 \mathrm{a}$ & $7.47 \pm 0.01 \mathrm{a}$ \\
\hline
\end{tabular}

2 Note: CB-bulk soil from cucumber monocropping; GB-bulk soil from green garlic intercropping with cucumber; CR-rhizosphere soil from cucumber monocropping; GR-

3 rhizosphere soil from green garlic intercropping with cucumber.

4 Data are means \pm standard error of $n=3$. Values followed by the same letter are not significantly different at the $5 \%$ level. 


\section{Table 2 (on next page)}

Fatty acid (mol\%) composition in the rhizosphere and bulk soils under intercropping and monocropping systems for different sampling dates

Data are means \pm standard error of $n=3$. Values followed by the same letter are not significantly different at the $5 \%$ level. 
1 Table 2a. Fatty acid (mol\%) composition in the rhizosphere soils under intercropping and monocropping systems for different

2 sampling dates

\begin{tabular}{|c|c|c|c|c|c|c|}
\hline \multirow[t]{2}{*}{ Fatty acids } & \multicolumn{2}{|c|}{15 days after interplantation } & \multicolumn{2}{|c|}{30 days after interplantation } & \multicolumn{2}{|c|}{45 days after interplantation } \\
\hline & Monocropping & Intercropping & Monocropping & Intercropping & Monocropping & Intercropping \\
\hline \multicolumn{7}{|l|}{$\mathbf{G}^{+}$} \\
\hline i14:0 & $0.80 \pm 0.03 \mathrm{a}$ & $0.71 \pm 0.01 \mathrm{~b}$ & $0.54 \pm 0.02 \mathrm{a}$ & $\begin{array}{l}0.57 \pm 0.02 \\
\mathrm{a}\end{array}$ & $0.60 \pm 0.03 \mathrm{a}$ & $0.52 \pm 0.02 a$ \\
\hline i15:0 & $6.95 \pm 0.07 \mathrm{a}$ & $6.25 \pm 0.14 b$ & $5.82 \pm 0.14 \mathrm{a}$ & $\begin{array}{l}\quad 6.21 \pm 0.12 \\
\mathrm{a}\end{array}$ & $5.98 \pm 0.05 b$ & $6.37 \pm 0.13$ \\
\hline a15:0 & $3.93 \pm 0.09 \mathrm{a}$ & $4.06 \pm 0.21 \mathrm{a}$ & $3.34 \pm 0.04 \mathrm{a}$ & $\begin{array}{l}3.05 \pm 0.06 \\
\mathrm{~b}\end{array}$ & $3.39 \pm 0.18 \mathrm{a}$ & $3.75 \pm 0.07$ \\
\hline i16:0 & $3.32 \pm 0.02 \mathrm{a}$ & $3.57 \pm 0.20 \mathrm{a}$ & $2.97 \pm 0.08 \mathrm{a}$ & $\begin{array}{l}2.57 \pm 0.06 \\
\mathrm{~b}\end{array}$ & $2.39 \pm 0.09 \mathrm{~b}$ & $2.83 \pm 0.08$ \\
\hline i17:0 & $2.74 \pm 0.17 \mathrm{~b}$ & $4.21 \pm 0.08 \mathrm{a}$ & $2.94 \pm 0.09 \mathrm{a}$ & $\begin{array}{l}3.32 \pm 0.19 \\
\text { a }\end{array}$ & $3.01 \pm 0.05 b$ & $3.69 \pm 0.08$ \\
\hline a17:0 & $2.60 \pm 0.19 b$ & $3.58 \pm 0.17 \mathrm{a}$ & $2.87 \pm 0.04 \mathrm{~b}$ & $\begin{array}{l}3.88 \pm 0.09 \\
\mathrm{a}\end{array}$ & $2.42 \pm 0.16 b$ & $3.75 \pm 0.07$ \\
\hline $\operatorname{Sum}\left(\mathrm{G}^{+}\right)$ & $20.34 \pm 0.33 b$ & $22.38 \pm 0.29 \mathrm{a}$ & $18.49 \pm 0.11 b$ & $\begin{array}{l}19.59 \pm 0.06 \\
\text { a }\end{array}$ & $17.80 \pm 0.19 b$ & $20.91 \pm 0.20$ \\
\hline \multicolumn{7}{|l|}{$\mathrm{G}^{-}$} \\
\hline $16: 1 \omega 7 \mathrm{c}$ & $11.11 \pm 0.15 \mathrm{a}$ & $8.92 \pm 0.15 b$ & $11.60 \pm 0.10 \mathrm{a}$ & $\begin{array}{l}11.49 \pm 0.15 \\
\mathrm{a}\end{array}$ & $9.48 \pm 0.09 \mathrm{~b}$ & $11.55 \pm 0.14$ \\
\hline cy17:0 & $2.41 \pm 0.10 \mathrm{a}$ & $2.48 \pm 0.21 \mathrm{a}$ & $2.35 \pm 0.05 \mathrm{a}$ & $\begin{array}{l}2.55 \pm 0.13 \\
\mathrm{a}\end{array}$ & $2.37 \pm 0.09 \mathrm{~b}$ & $3.06 \pm 0.14 \mathrm{a}$ \\
\hline cy19:0 & $5.35 \pm 0.21 \mathrm{a}$ & $5.30 \pm 0.10 \mathrm{a}$ & $5.03 \pm 0.04 \mathrm{a}$ & $\begin{array}{l}5.01 \pm 0.17 \\
\mathrm{a}\end{array}$ & $4.66 \pm 0.13 b$ & $5.45 \pm 0.20 \mathrm{a}$ \\
\hline $\operatorname{Sum}\left(\mathrm{G}^{-}\right)$ & $18.87 \pm 0.38 \mathrm{a}$ & $16.70 \pm 0.04 \mathrm{~b}$ & $18.99 \pm 0.09 \mathrm{a}$ & $\begin{array}{l}19.05 \pm 0.15 \\
\mathrm{a}\end{array}$ & $16.51 \pm 0.25 b$ & $20.05 \pm 0.38$ \\
\hline Actinomycetes & & & & & & \\
\hline
\end{tabular}




\begin{tabular}{|c|c|c|c|c|c|c|}
\hline 10Me $16: 0$ & $14.04 \pm 0.13 \mathrm{a}$ & $13.15 \pm 0.20 \mathrm{~b}$ & $12.06 \pm 0.15 b$ & $\begin{array}{l}13.98 \pm 0.33 \\
\text { a }\end{array}$ & $15.36 \pm 0.18 b$ & $20.61 \pm 0.12 a$ \\
\hline 10Me 17:0 & $0.77 \pm 0.03 \mathrm{a}$ & $0.66 \pm 0.02 b$ & $0.93 \pm 0.01 \mathrm{a}$ & $\begin{array}{l}0.56 \pm 0.01 \\
\mathrm{~b}\end{array}$ & $0.48 \pm 0.03 \mathrm{a}$ & $0.60 \pm 0.05 \mathrm{a}$ \\
\hline 10Me 18:0 & $4.57 \pm 0.16 b$ & $7.18 \pm 0.28 \mathrm{a}$ & $3.14 \pm 0.03 \mathrm{~b}$ & $\begin{array}{l}4.72 \pm 0.11 \\
\mathrm{a}\end{array}$ & $7.71 \pm 0.06 \mathrm{a}$ & $7.40 \pm 0.12 \mathrm{a}$ \\
\hline $\operatorname{Sum}(\mathrm{A})$ & $19.38 \pm 0.09 b$ & $20.99 \pm 0.31 \mathrm{a}$ & $16.13 \pm 0.17 b$ & $\begin{array}{l}19.26 \pm 0.39 \\
\text { a }\end{array}$ & $23.55 \pm 0.10 b$ & $28.62 \pm 0.10 \mathrm{a}$ \\
\hline \multicolumn{7}{|l|}{ Fungi } \\
\hline $18: 1 \omega 9 \mathrm{c}$ & $7.30 \pm 0.11 \mathrm{a}$ & $6.47 \pm 0.10 \mathrm{~b}$ & $7.09 \pm 0.09 \mathrm{a}$ & $\begin{array}{l}5.80 \pm 0.09 \\
\mathrm{~b}\end{array}$ & $6.46 \pm 0.12 \mathrm{a}$ & $4.88 \pm 0.14 b$ \\
\hline $18: 2 \omega 6,9$ & $3.05 \pm 0.08 \mathrm{a}$ & $3.27 \pm 0.18 \mathrm{a}$ & $3.28 \pm 0.03 \mathrm{a}$ & $\begin{array}{l}1.69 \pm 0.08 \\
\mathrm{~b}\end{array}$ & $2.70 \pm 0.09 \mathrm{a}$ & $1.24 \pm 0.06 \mathrm{~b}$ \\
\hline $\operatorname{Sum}(F)$ & $10.35 \pm 0.19 \mathrm{a}$ & $9.74 \pm 0.27 \mathrm{a}$ & $10.37 \pm 0.06 \mathrm{a}$ & $\begin{array}{l}7.49 \pm 0.09 \\
b\end{array}$ & $9.16 \pm 0.03 \mathrm{a}$ & $6.12 \pm 0.09 \mathrm{~b}$ \\
\hline \multicolumn{7}{|l|}{ AMF } \\
\hline $16: 1 \omega 5 \mathrm{c}$ & $3.33 \pm 0.09 \mathrm{~b}$ & $4.70 \pm 0.16 \mathrm{a}$ & $2.34 \pm 0.04 \mathrm{~b}$ & $\begin{array}{l}2.54 \pm 0.03 \\
\mathrm{a}\end{array}$ & $2.41 \pm 0.03 b$ & $3.32 \pm 0.08 \mathrm{a}$ \\
\hline \multicolumn{7}{|l|}{ Protozoa } \\
\hline $20: 4 \omega 6 c$ & $1.11 \pm 0.05 \mathrm{~b}$ & $1.75 \pm 0.06 \mathrm{a}$ & $0.43 \pm 0.03 \mathrm{~b}$ & $\begin{array}{l}0.69 \pm 0.01 \\
\mathrm{a}\end{array}$ & $0.46 \pm 0.02 \mathrm{~b}$ & $0.66 \pm 0.01 \mathrm{a}$ \\
\hline
\end{tabular}


4 Table 2 b. Fatty acid (mol\%) composition in the bulk soils under intercropping and monocropping systems for different

\section{5 sampling dates}

\begin{tabular}{|c|c|c|c|c|c|c|}
\hline \multirow[t]{2}{*}{ Fatty acids } & \multicolumn{2}{|c|}{15 days after interplantation } & \multicolumn{2}{|c|}{30 days after interplantation } & \multicolumn{2}{|c|}{45 days after interplantation } \\
\hline & Monocropping & Intercropping & Monocropping & Intercropping & Monocropping & Intercropping \\
\hline \multicolumn{7}{|l|}{$\mathbf{G}^{+}$} \\
\hline i14:0 & $0.62 \pm 0.02 \mathrm{a}$ & $0.63 \pm 0.03 \mathrm{a}$ & $0.57 \pm 0.02 \mathrm{a}$ & $0.66 \pm 0.02 \mathrm{a}$ & $0.58 \pm 0.01 \mathrm{a}$ & $0.54 \pm 0.03 \mathrm{a}$ \\
\hline i15:0 & $6.20 \pm 0.00 \mathrm{a}$ & $6.06 \pm 0.09 \mathrm{a}$ & $\begin{array}{l}5.32 \pm 0.06 \\
b\end{array}$ & $6.64 \pm 0.08 \mathrm{a}$ & $5.46 \pm 0.17 \mathrm{a}$ & $5.89 \pm 0.14 \mathrm{a}$ \\
\hline a15:0 & $3.45 \pm 0.09 \mathrm{a}$ & $3.37 \pm 0.04 \mathrm{a}$ & $3.24 \pm 0.03 \mathrm{~b}$ & $3.82 \pm 0.08 \mathrm{a}$ & $3.34 \pm 0.10 \mathrm{a}$ & $3.55 \pm 0.08 \mathrm{a}$ \\
\hline i16:0 & $3.02 \pm 0.03 \mathrm{~b}$ & $2.83 \pm 0.06 \mathrm{a}$ & $2.68 \pm 0.03 \mathrm{a}$ & $3.02 \pm 0.16 \mathrm{a}$ & $2.82 \pm 0.08 \mathrm{a}$ & $3.07 \pm 0.11 \mathrm{a}$ \\
\hline i17:0 & $2.12 \pm 0.02 b$ & $4.25 \pm 0.07 \mathrm{a}$ & $3.03 \pm 0.03 \mathrm{a}$ & $3.02 \pm 0.07 \mathrm{a}$ & $1.98 \pm 0.03 \mathrm{~b}$ & $3.86 \pm 0.15 \mathrm{a}$ \\
\hline a17:0 & $2.12 \pm 0.03 \mathrm{~b}$ & $3.55 \pm 0.03 \mathrm{a}$ & $2.76 \pm 0.09 \mathrm{a}$ & $2.99 \pm 0.02 \mathrm{a}$ & $2.01 \pm 0.01 \mathrm{~b}$ & $3.14 \pm 0.10 \mathrm{a}$ \\
\hline $\operatorname{Sum}\left(G^{+}\right)$ & $17.53 \pm 0.08 b$ & $20.69 \pm 0.20 \mathrm{a}$ & $17.61 \pm 0.16 \mathrm{~b}$ & $20.14 \pm 0.28 \mathrm{a}$ & $16.19 \pm 0.09 \mathrm{~b}$ & $20.04 \pm 0.34 \mathrm{a}$ \\
\hline \multicolumn{7}{|l|}{$\mathrm{G}^{-}$} \\
\hline $16: 1 \omega 7 \mathrm{c}$ & $8.25 \pm 0.13 \mathrm{a}$ & $8.53 \pm 0.13 \mathrm{a}$ & $11.11 \pm 0.01 \mathrm{a}$ & $9.54 \pm 0.16 b$ & $8.83 \pm 0.22 b$ & $10.51 \pm 0.15 \mathrm{a}$ \\
\hline cy17:0 & $1.88 \pm 0.04 \mathrm{~b}$ & $2.58 \pm 0.08 \mathrm{a}$ & $2.41 \pm 0.10 \mathrm{a}$ & $2.38 \pm 0.07 \mathrm{a}$ & $1.94 \pm 0.01 b$ & $2.64 \pm 0.03 \mathrm{a}$ \\
\hline cy19:0 & $4.98 \pm 0.04 \mathrm{a}$ & $4.72 \pm 0.01 \mathrm{~b}$ & $4.67 \pm 0.02 b$ & $6.03 \pm 0.06 \mathrm{a}$ & $4.47 \pm 0.10 \mathrm{a}$ & $4.52 \pm 0.23 \mathrm{a}$ \\
\hline $\operatorname{Sum}\left(G^{-}\right)$ & $15.11 \pm 0.13 b$ & $15.83 \pm 0.20 \mathrm{a}$ & $18.19 \pm 0.11 \mathrm{a}$ & $17.96 \pm 0.15 \mathrm{a}$ & $15.24 \pm 0.14 \mathrm{~b}$ & $17.68 \pm 0.11 \mathrm{a}$ \\
\hline \multicolumn{7}{|c|}{ Actinomycetes } \\
\hline 10Me 16:0 & $13.94 \pm 0.16 b$ & $16.53 \pm 0.27 \mathrm{a}$ & $12.77 \pm 0.08 \mathrm{~b}$ & $16.46 \pm 0.19 \mathrm{a}$ & $14.22 \pm 0.23 b$ & $18.24 \pm 0.12 \mathrm{a}$ \\
\hline 10Me 17:0 & $0.59 \pm 0.01 \mathrm{a}$ & $0.51 \pm 0.01 \mathrm{~b}$ & $0.58 \pm 0.03 \mathrm{a}$ & $0.70 \pm 0.05 \mathrm{a}$ & $0.71 \pm 0.04 \mathrm{a}$ & $0.51 \pm 0.01 b$ \\
\hline 10Me 18:0 & $3.97 \pm 0.03 \mathrm{a}$ & $3.15 \pm 0.13 b$ & $2.44 \pm 0.08 \mathrm{~b}$ & $4.59 \pm 0.17 \mathrm{a}$ & $5.72 \pm 0.06 \mathrm{~b}$ & $6.52 \pm 0.14 \mathrm{a}$ \\
\hline $\operatorname{Sum}(\mathrm{A})$ & $18.50 \pm 0.16 b$ & $20.19 \pm 0.34 \mathrm{a}$ & $15.79 \pm 0.11 b$ & $21.75 \pm 0.07 \mathrm{a}$ & $20.66 \pm 0.14 b$ & $25.27 \pm 0.09 \mathrm{a}$ \\
\hline \multicolumn{7}{|l|}{ Fungi } \\
\hline $18: 1 \omega 9 \mathrm{c}$ & $7.75 \pm 0.02 \mathrm{a}$ & $7.31 \pm 0.07 b$ & $6.61 \pm 0.22 \mathrm{a}$ & $7.04 \pm 0.14 \mathrm{a}$ & $7.06 \pm 0.04 \mathrm{a}$ & $4.64 \pm 0.11 b$ \\
\hline $18: 2 \omega 6,9$ & $4.25 \pm 0.15 \mathrm{a}$ & $1.76 \pm 0.03 \mathrm{~b}$ & $4.52 \pm 0.16 \mathrm{a}$ & $2.40 \pm 0.11 \mathrm{~b}$ & $1.86 \pm 0.04 \mathrm{~b}$ & $2.48 \pm 0.16 \mathrm{a}$ \\
\hline $\operatorname{Sum}(F)$ & $12.00 \pm 0.14 \mathrm{a}$ & $9.07 \pm 0.08 b$ & $11.13 \pm 0.06 \mathrm{a}$ & $9.45 \pm 0.06 \mathrm{~b}$ & $8.91 \pm 0.02 \mathrm{a}$ & $7.12 \pm 0.06 b$ \\
\hline
\end{tabular}




\begin{tabular}{|c|c|c|c|c|c|c|}
\hline \multicolumn{7}{|l|}{$\mathrm{AMF}$} \\
\hline $16: 1 \omega 5 c$ & $2.70 \pm 0.03 b$ & $2.80 \pm 0.01 \mathrm{a}$ & $2.31 \pm 0.02 b$ & $2.95 \pm 0.08 \mathrm{a}$ & $2.51 \pm 0.03 b$ & $3.48 \pm 0.05 b$ \\
\hline \multicolumn{7}{|l|}{ Protozoa } \\
\hline $20: 4 \omega 6 c$ & $0.40 \pm 0.01 \mathrm{~b}$ & $0.47 \pm 0.01 \mathrm{a}$ & $0.33 \pm 0.02 \mathrm{~b}$ & $0.57 \pm 0.00 \mathrm{a}$ & $0.37 \pm 0.02 \mathrm{~b}$ & $0.59 \pm 0.01 \mathrm{a}$ \\
\hline
\end{tabular}

6 Note: Data are means \pm standard error of $n=3$. Values followed by the same letter are not significantly different at the $5 \%$ level. 


\section{Table 3(on next page)}

Correlations ( $r$ ) between soil chemical, microbiological, and biochemical parameters $d$ for monocropping and intercropping systems

NS Correlation is not significant. * Correlation is significant at 0.05 level. ** Correlation is significant at 0.01 level. ${ }^{* * *}$ Correlation is significant at 0.001 level. 
1 Table 3a. Correlations (r) between soil chemical, microbiological, and biochemical parameters d for monocropping systems

\begin{tabular}{|c|c|c|c|c|c|c|c|c|c|c|c|c|c|}
\hline & Bacteria & Actinomycetes & Fungi & $\begin{array}{c}\text { Total } \\
\text { microbial } \\
\text { biomass }\end{array}$ & $\begin{array}{c}\text { Available } \\
\mathrm{N}\end{array}$ & $\begin{array}{c}\text { Available } \\
\text { P }\end{array}$ & $\begin{array}{c}\text { Available } \\
\text { K }\end{array}$ & $\mathrm{pH}$ & $\begin{array}{l}\text { Organic } \\
\text { carbon }\end{array}$ & Urease & Invertase & $\begin{array}{c}\text { Alkaline } \\
\text { phosphatase }\end{array}$ & Catalase \\
\hline Bacteria & - & NS & NS & $0.89 *$ & $0.83 *$ & $0.93^{* *}$ & NS & $0.91 *$ & $0.97 * *$ & $0.98^{* * *}$ & $0.88^{*}$ & $0.97^{* *}$ & NS \\
\hline Actinomycetes & & - & $0.90^{*}$ & NS & NS & $0.81^{*}$ & $0.91^{*}$ & NS & NS & NS & NS & NS & NS \\
\hline Fungi & & & - & NS & NS & $0.89 *$ & $0.86^{*}$ & NS & NS & NS & $0.90^{*}$ & $0.83^{*}$ & NS \\
\hline $\begin{array}{l}\text { Total } \\
\text { microbial } \\
\text { biomass }\end{array}$ & & & & - & $0.91 *$ & $0.95^{*}$ & NS & NS & $0.92 *$ & $0.90^{*}$ & $0.96 * *$ & $0.88^{*}$ & $0.83^{*}$ \\
\hline Available N & & & & & - & $0.92 *$ & $0.94 * *$ & $0.87^{*}$ & $0.94 * *$ & $0.82 *$ & $0.95^{* *}$ & $0.89 *$ & NS \\
\hline Available P & & & & & & - & $0.88^{*}$ & $0.83^{*}$ & $0.95^{* *}$ & $0.92 *$ & $0.97 * *$ & $0.96^{* *}$ & NS \\
\hline Available K & & & & & & & - & NS & $0.87^{*}$ & NS & $0.88^{*}$ & $0.87^{*}$ & NS \\
\hline $\mathrm{pH}$ & & & & & & & & - & $0.93 * *$ & $0.92 * *$ & $0.85^{*}$ & $0.90^{*}$ & NS \\
\hline $\begin{array}{l}\text { Organic } \\
\text { carbon }\end{array}$ & & & & & & & & & - & $0.93^{* *}$ & $0.93^{* *}$ & $0.98 * *$ & NS \\
\hline Urease & & & & & & & & & & - & $0.90^{*}$ & $0.92 * *$ & NS \\
\hline Invertase & & & & & & & & & & & - & $0.90^{*}$ & NS \\
\hline $\begin{array}{l}\text { Alkaline } \\
\text { phosphatase }\end{array}$ & & & & & & & & & & & & - & NS \\
\hline Catalase & & & & & & & & & & & & & - \\
\hline
\end{tabular}

5 Table 3b. Correlations (r) between soil chemical, microbiological, and biochemical parameters for intercropping systems 


\begin{tabular}{|c|c|c|c|c|c|c|c|c|c|c|c|c|c|}
\hline & Bacteria & Actinomycetes & Fungi & $\begin{array}{c}\text { Total } \\
\text { microbial } \\
\text { biomass }\end{array}$ & $\begin{array}{c}\text { Available } \\
\mathrm{N}\end{array}$ & $\begin{array}{c}\text { Available } \\
\text { P }\end{array}$ & $\begin{array}{c}\text { Available } \\
\text { K }\end{array}$ & $\mathrm{pH}$ & $\begin{array}{l}\text { Organic } \\
\text { carbon }\end{array}$ & Urease & Invertase & $\begin{array}{c}\text { Alkaline } \\
\text { phosphatase }\end{array}$ & Catalase \\
\hline Bacteria & - & $-0.83^{*}$ & $\begin{array}{c}- \\
0.81 *\end{array}$ & NS & NS & NS & NS & NS & NS & NS & NS & $0.93 * *$ & NS \\
\hline Actinomycetes & & - & NS & NS & NS & $0.88^{*}$ & $0.94 * *$ & NS & NS & NS & NS & $0.92 * *$ & NS \\
\hline Fungi & & & - & NS & NS & NS & NS & NS & NS & NS & NS & NS & NS \\
\hline $\begin{array}{l}\text { Total } \\
\text { microbial } \\
\text { biomass }\end{array}$ & & & & - & $0.84^{*}$ & NS & NS & NS & NS & $0.87^{*}$ & NS & NS & NS \\
\hline Available N & & & & & - & $0.89 *$ & $0.82 *$ & NS & $0.84 *$ & $0.95^{* *}$ & $0.88^{*}$ & NS & NS \\
\hline Available P & & & & & & - & $0.97 * *$ & $0.82 *$ & $0.84 *$ & NS & NS & NS & NS \\
\hline Available K & & & & & & & - & $0.86^{*}$ & $0.83 *$ & NS & NS & $0.89^{*}$ & NS \\
\hline $\mathrm{pH}$ & & & & & & & & - & $0.92 * *$ & NS & NS & NS & NS \\
\hline $\begin{array}{l}\text { Organic } \\
\text { carbon }\end{array}$ & & & & & & & & & - & $0.84^{*}$ & NS & NS & NS \\
\hline Urease & & & & & & & & & & - & $0.87^{*}$ & NS & NS \\
\hline Invertase & & & & & & & & & & & - & NS & NS \\
\hline $\begin{array}{l}\text { Alkaline } \\
\text { phosphatase }\end{array}$ & & & & & & & & & & & & - & NS \\
\hline Catalase & & & & & & & & & & & & & - \\
\hline
\end{tabular}

7 Note: NS Correlation is not significant. * Correlation is significant at 0.05 level. ** Correlation is significant at 0.01 level. *** Correlation is significant at 0.001 level. 